\title{
FURTHER STUDIES IN THE GENUS
}

\section{DODONAEA}

\author{
BY \\ EARL EDWARD SHERFF \\ RESEARCH ASSOCIATE, SYSTEMATIC BOTANY
}

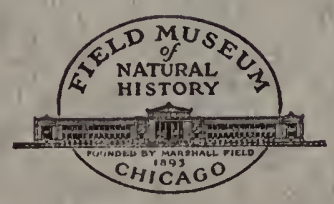

BOTANICAL SERIES

FIELD MUSEUM OF NATURAL HISTORY

VOLUME 23, NUMBER 6

DECEMBER 22, 1947

PUBLICATION 612 




\section{FURTHER STUDIES IN THE GENUS DODONAEA}

BY

EARL EDWARD SHERFF

RESEARCH ASSOCIATE, SYSTEMATIC BOTANY

\section{This is COPY No. 54 OF A SPECIAL EDITION LIMITED TO 103 COPIES}

PRINTED FOR DR, EARL E. SHERFF

ON

\section{P E R M A N N T P A P E R}

BOTANICAL SERIES

FIELD MUSEUM OF NATURAL HISTORY

VOLUME 23, NUMBER 6

DECEMBER 22, 1947

PUBLICATION 612

THE LIBRARY OF THE

APR 169948

UNIVERSITY OF ILLINOIS 



\title{
FURTHER STUDIES IN THE GENUS DODONAEA
}

\author{
BY \\ EARL EDWARD SHERFF \\ RESEARCH ASSOCIATE, SYSTEMATIC BOTANY
}

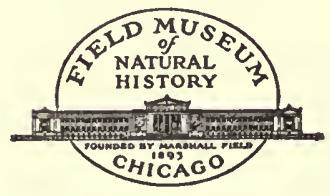

BOTANICAL SERIES

FIELD MUSEUM OF NATURAL HISTORY

VOLUME 23, NUMBER 6

DECEMBER 22, 1947

PUBLICATION 612

THE LIBRARY OF THE

APR 169988

UNIVERSITY OF ILLINOIS 
PRINTED IN THE UNITED STATES OF AMERICA BY FIELD MUSEUM PRESS 


\title{
FURTHER STUDIES IN THE GENUS DODONAEA L.
}

\author{
(FAMILY SAPINDACEAE) ${ }^{1}$
}

EARL EDWARD SHERFF

Dodonaea viscosa (L.) Jacq. Enum. Syst. Pl. 19. 1760. Staphylodendron foliis lauri angustis Plum. Cat. Pl. Amer. p. 18, 1703 and Pl. Amer. Ic. edit. Burm. fasc. 10: 246. 1760. Aceri vel palituro [sic! re vera paliuro] affinis, angusto oblongo ligustri folio, flore tetrapetalo herbaceo Sloane Nat. Hist. Jamaica $1^{\mathrm{II}}: 27$, and 2: tab. 162, f. 3. 1707. Dodonaea L. Hort. Cliff. 144. 1737. Ptelea viscosa L. Sp. Pl.118. 1753. Ptelea foliis simplicibus Plum. op. secund. cit. tab. 247, f. 2. ${ }^{2}$

The synonymy for Dodonaea viscosa proper is exceptionally large and must be omitted here for the most part. It was treated in great detail by Radlkofer in Martius' Flora Brasiliensis (13, pt. 3: 639-645. 1900). The combination $D$. viscosa begins with Jacquin (loc. cit.). Jacquin gave no detailed description, but cited the Sloane plate $162, f .3$ (above listed). If we stop with the Sloane figure, as those who cite only Jacquin for the authorship of $D$. viscosa apparently do, we fix the type of the species proper as a Jamaica plant with leaves fairly large (and not very numerous), spatulate to broadly oblanceolate, apically obtuse to rounded, and very distinctly veined.

However, there is every reason to believe that Jacquin merely adapted the trivial name viscosa from Ptelea viscosa L. (vide supra). ${ }^{3}$ This being the case, we may trace the Linnaean concept directly to Hortus Cliffortianus p. 144. There the first reference given is to Staphylodendron foliis lauri angustis Plum. Cat. 18. This reference to Plumier's Catalogue is supported only by the heading to the list of names among which it stands (in Plumier's Catalogue), and from this heading we learn that the plant had been described and delineated by Plumier himself in the "Insulis Americanis." His delineations appeared later in fascicle 10 of his large work on American plants, edited by Burmann (vide supra), and in figure 2 of plate 247 of that work we come to an illustration that, with better claim than

1 For an earlier paper on Dodonaea, vide Amer. Journ. Bot. 32: 202-214. 1945.

${ }^{2}$ A conspectus of the varieties and formae of Dodonaea viscosa treated in this article will be found beginning on page 308 .

${ }^{3}$ Indeed, many authors, Bentham among them, have ignored Jacquin altogether and accredited the combination $D$. viscosa entirely to Linnaeus. 
the Sloane sketch, may serve as the type basis for Dodonaea viscosa in its narrowest sense. The spray shown has only five leaves. These are less or indeed not at all narrowed toward the base, the two largest being one narrowly and one moderately oblong. All are somewhat acute or acutish at the apex. The latter of these two oblong leaves is identically the broad kind characteristic of the forma repanda described by Radlkofer (loc. cit.) and based by him upon Dodonaea repanda Schum. \& Thonn. Beskr. Guin. Pl. in Danske Vidensk. Selsk. Afhandl. III: 214 (seors. impr. p. 194), no. 1. 1828.1 Radlkofer described the forma repanda so as to include not only the very form shown in the Plumier plate but the one shown in Sloane's. Moreover, he cited these two illustrations for f. repanda but somewhat guardedly with the abbreviation " $c f$. ." In nature, the two vary so much that, rather than employ a lesser rank of subforma for each, we might well leave them together as constituting a highly variable forma, namely, f. repanda.

Several varieties have been proposed for $D$. viscosa, but apparently the first one described intentionally as representing the typical form of the species was var. vulgaris Benth. Fl. Austral. 1: 476. 1863.

Bentham made an exhaustive study of the forty or more species of Dodonaea known in his day and found that most of the extraAustralian forms were referable to his $D$. viscosa var. vulgaris or to one or the other of two other varieties that he established for $D$. viscosa, viz., vars. angustifolia and spatulata. ${ }^{2}$ He excepted "perhaps, the D. eriocarpa from the Sandwich Islands, D. Thunbergiana, Eckl. and Zeyh., from S. Africa, and one or two Mexican ones, which, whether varieties or species, do not occur in Australia." Bentham remarked upon the "almost protean forms the species assumes in Australia" and added that they "are very difficult to distribute into definite varieties."

In 1900 appeared the exceptionally able and brilliant treatment of $D$. viscosa by Radlkofer, already cited. Radlkofer (p. 646) accepted Bentham's three varieties, but listed only vars. vulgaris and angustifolia for Brazil, with the flora of which he at that time was concerned exclusively. He subdivided var. vulgaris into three formae for Brazil,

1 This leaf is shown somewhat apart from the other four and arises from a main branch on a side shoot of which the other four are borne. The artist superimposed a large fruiting cluster above much of it and thus possibly some earlier workers have overlooked or ignored it. Fortunately, however, fully enough of its median and lower blade is shown to make identification certain.

2 Bentham's spelling was spathulata, but the original spelling by Sir James E. Smith, from whom he derived the name, was spatulata. 
viz., repanda (Schum. \& Thonn.) Radlk., Schiedeana (Schlecht.) Radlk., and Burmanniana (Schum. \& Thonn.) Radlk. Var. angustifolia he left intact.

Like Bentham, he had been impressed with the extreme polymorphism in $D$. viscosa. Thus he wrote: "Miro modo ludit forma et magnitudine foliorum fructuumque. Varietates 3 cum cl. Bentham (in Fl. Australiensi) discernere par est, a vulgarem, $\beta$ angustifoliam, $\gamma$ spathulatam, quae formas varias alias in alias transeuntes includunt. E Brasilia non nisi var. $\alpha$ et $\beta$ et formae sequentes [repanda, Schiedeana, et Burmanniana] innotuerunt." Radlkofer's nomenclature, based as it was on rules since altered by international congresses, has been found to need revision. The required changes have recently been published (Amer. Journ. Bot. 32: 214. 1945) and the detailed explanations pertaining thereto are given in the present paper. Radlkofer's general understanding of the plant entities themselves, however, is seen to have been so trustworthy that we may well commence here an interpretation of $D$. viscosa with an abridged translation of his description and conspectus of $D$. viscosa vars. vulgaris, including its component formae, and angustifolia. Of necessity, these were more or less arbitrary. He described $D$. viscosa collectively as: Slender trees 3-5 meters tall or branched shrubs 1-3 meters tall. Branches erect, the floriferous ones 2-3 mm. thick, bark brown or dark. Leaves (petiole $0.2-1 \mathrm{~cm}$. long included) now up to $12 \mathrm{~cm}$. long, $4 \mathrm{~cm}$. wide (f. repanda), now up to $15 \mathrm{~cm}$. long, only $2 \mathrm{~cm}$. wide (f. Schiedeana), now 7-10 cm. long, 1.5-2 cm. wide (f. Burmanniana), now 7-9 $\mathrm{cm}$. long, $0.5-1 \mathrm{~cm}$. wide (var. angustifolia). Thyrses subequal to half the foliar length, longer in fruit; pedicels at anthesis $0.5-0.8 \mathrm{~cm}$. or in fruit $1-1.5 \mathrm{~cm}$. long. Flowers $3 \mathrm{~mm}$. long, whitishgreen. Sepals $3 \mathrm{~mm}$. long, $1.5 \mathrm{~mm}$. wide, 3-nerved, puberulous especially at margin and apex. Stamineal filaments scarcely $1 \mathrm{~mm}$. long, anthers $2.5 \mathrm{~mm}$. long. Capsule now larger, suborbicular (its wings subequal to the locules in width included), $2.2 \mathrm{~cm}$. long, 2.5 $\mathrm{cm}$. wide; now mediocre, obcordate, $1.5 \mathrm{~cm}$. long and $1.8 \mathrm{~cm}$. wide; now small, about $1 \mathrm{~cm}$. in diameter, sanguineous when fresh, in dry state brownish or stramineous. Seeds about $2.5 \mathrm{~mm}$. across.

Of considerable additional aid to the student of $D$. viscosa are the short, summarizing descriptions that Radlkofer gave (op. cit. 646). These are repeated essentially as he presented them:

Var. a vulgaris Benth.: Folia sat larga, subobovata, ex oblongo latiuscule vel elongate vel anguste lanceolata, vel ex oblongo-lance- 
olata cuneato-attenuata; capsula suborbicularis vel obcordata sat magna.

Forma 1. repanda. . . Folia maxima ex oblongo latiuscule lanceolata utrinque acuta vel apice obtusa, inde subobovata; fructus plerumque maximi, suborbiculares, 3-alati vel 2-alati quoque in eadem inflorescentia. ... .

Forma 2. Schiedeana. . . Folia longissima, elongate lanceolata, utrinque sensim acutata; fructus sat magni, orbiculares vel subobcordati, utrinque vel apice tantum emarginati, sinu apicali saepius largiore. . . .

Forma 3. Burmanniana. ... Folia mediocria, ex oblongo anguste lanceolata cuneatave, apice acuta vel obtusiuscula, in petiolum longius breviusve attenuata; fructus mediocres, suborbiculares, apice et basi excisi vel subobcordati, basi vix excisi. . . .

Var. $\beta$ angustifolia Benth.: Folia angusta, lineari-lanceolata vel sublinearia, longiora vel breviora; fructus minores, utrinque vel apice tantum excisi, alis saepius latioribus. . . .

Some years ago, I was invited by Mr. Otto Degener, well-known authority on the Hawaiian Island flora, to determine the numerous collections of Dodonaea that he had made in the Hawaiian Islands. I accepted the task but I soon found that it necessitated a comparative study of a vast amount of material from other regions of the earth. Several American and European herbaria cooperated by lending all or part of their Dodonaea material, and assistance and encouragement were given from time to time by their custodians, especially by Dr. Albert C. Smith, Curator of the Herbarium of Arnold Arboretum. It is a pleasure to acknowledge here my indebtedness to these institutions and botanists.

As the specimens of Dodonaea viscosa in herbaria have been observed to have been only too often misdetermined, or else undetermined to the proper variety or forma, I have had occasion to label many hundreds in accordance with the nomenclatural results of the present study. Many of these are cited later in this paper, but some of those determined for Radlkofer's three formae of var. vulgaris Benth. are listed here for the aid they may afford to other workers: ${ }^{1}$

1 The following abbreviations are used for the depositories of specimens cited in this paper: Arn., Arnold Arboretum, Jamaica Plain; Bail., Herbarium of Liberty Hyde Bailey, Ithaca; Berl., Berlin Botanical Garden; Bish., Bernice P. Bishop Museum, Honolulu; Calif., University of California, Berkeley; Carn., Carnegie Museum, Pittsburgh; Chi., Field Museum of Natural History, Chicago; Corn., 
Specimens examined for f. 1. repanda (Schum. \& Thonn.) Radlk.: ${ }^{1}$

Florida: Otto Frank, Pinellas, December, 1899, to April, 1900 (N.Y.); Frederick L. Lewton, Disston City, August 5, 1894 (N.Y.); Harold N. Moldenke 3576, in hammock, Miami, December 24, 1927 (N.Y.); John K. Small 10421, coastal sand-dunes west of Cat Point, April 23, 1922 (Gray; N.Y.).

Clarion Island: John T. Howell 8363 pro parte, Sulphur Bay, March 23, 1932 (N.Y.).

Baja California: Marcus $E$. Jones, trail down the Lagunas, west side, September 24, 1930 (Calif., sub nom. D. lagunensi M.E.J.); Jones, Cayuca Ranch, Loreto, October 23, 1930 (N.Y., sub nom. D. lagunensi M.E.J.); Nelson \& Goldman 7438, shrub 10-20 feet tall, alt. 3,000-4,500 feet, road from San Bernardo to Sierra La Laguna, January 21, 1906 (Gray).

Nuevo León: C. H. \& M. T. Mueller 335, Diente Canyon, mountains near Monterey, July, 1933 (Chi.).

Hidalgo: $V$. H. Chase 7401, alt. 5,000 feet, mountain ravine, Jacala, July 10, 1939 (Chi.; N.Y.).

Guanajuato: Alfredo Dugès, City of Guanajuato and vicinity, April, 1898 (Gray).

Guerrero: Ruth $Q$. Abbott 179, small tree or shrub, native name chapulixtle, Taxco, December 23, 1936 (Gray); Abbott 220, small tree or shrub, very common, Taxco, June 14, 1937 (Gray).

Cornell University, Ithaca; Deg., Herbarium of Otto Degener (until recently of Honolulu); Del., Delessert Herbarium, Geneva; Flor., Institute of Botany of University of Florence; Goth., Arboretum (or Botanical Garden) of Gothenburg; Gray, Gray Herbarium of Harvard University, Cambridge; Kew, Royal Botanical Gardens, Kew; Len., Botanical Garden of Leningrad (Hortus Petropolitanus); Minn., University of Minnesota, Minneapolis; Mo., Missouri Botanical Garden, St. Louis; Mun., Botanical Museum of Munich; Mus. V., Natural History Museum of Vienna; N.Y., New York Botanical Garden; Par., Museum of Natural History, Paris; Penn., Úniversity of Pennsylvania, Philadelphia; Phila., Academy of Natural Sciences, Philadelphia; U.S., United States National Museum, Washington, D.C.; U.V., University of Vienna; Yunck., Herbarium of Dr. Truman G. Yuncker, Greencastle, Indiana.

1 Radlkofer (op. cit. 646) cites also the State of Maranhão, Brazil, for $\mathrm{f}$. repanda, although no authentic specimen of f. repanda from that state has been available to me.

It may be noted here that $\mathrm{f}$. repanda is the f. typica of certain later writers (e.g., Robinson, Fl. Galapagos Isls., Proc. Amer. Acad. 38: 171. 1902; Herter, Rev. Sudam. Bot. 5: 35. 1937). We may note, too, that Otto Kuntze published (Rev. Gen. Pl. 1: 143. 1891), prior to Radlkofer's establishment of the forma repanda, the names viridula (" 1 . viridula 0 . Ktze. Flos viridulus antheris albis. Java, in Strandnähe") and lilacina ("2. lilacina O. Ktze. Flores apice lilacini. Silla de Caracas") for specimens of $D$. viscosa var. vulgaris. However, Kuntze used these names loosely, omitting formal assignment of definite rank, so that they remain of uncertain status and cannot invalidate the name repanda for the rank of a forma. 
British Honduras: William A. Schipp 494, height 6 feet, trunk diameter 2 inches, along sea-beach, Stann Creek, December 9, 1929 (Calif.; Chi.; Gray; N.Y.).

Guatemala: Alexander F. Skutch 1005 p. p., alt. 6,800 feet, on bushy mountain side, San Miguel Acatan, Dept. Huehuetenango, August 18, 1934 (Chi.); Paul C. Standley 82390, shrub 1-1.5 meters tall, sandy river-bed, alt. circ. 1,780 meters, Río Pucal, circ. 14 km. south of Huehuetenango, January 4, 1941 (Chi.).

Honduras: M. A. Carleton 619, Puerto Cortez, August 15, 1924 (Gray); Paul C. Standley 53038, shrub 5 feet tall, in thicket along beach, vicinity of Tela, Dept. Atlántida, December 14, 1927, to March 15, 1928 (Chi.); Percy Wilson 13, sandy soil between Highland Creek and sea, Puerto Sierra, January 15, 1903 (N.Y.).

Nicaragua: Charles L. Smith 92, shrub 4-7 feet tall, vicinity of San Juan del Norte (Greytown), November 25, 1895 (Gray; N.Y.).

Costa Rica: Fernando Solis R., no. 557, alt. 50 meters, La Barra, February 5, 1939 (Chi.).

Panama: V.C. Dunlap 480, small tree along beach, Bar Mouth, Changuinola Valley, Prov. Bocas del Toro, March 2, 1924 (Chi.).

Colombia: I. F. Holton, Choachí, January 18, 1854 (N.Y.).

Venezuela: $H$. Pittier 24, native name chaparro, on dry hills, Avila, March, 1937 (Chi.); Llewelyn Williams 12305, shrub, alt. 800 meters, common the whole length of old highway between Caracas and La Guaira, Distr. Fed., January 4, 1940 (Chi., 2 sheets); Williams 12369, shrub up to $8 \mathrm{dm}$. tall, among low shrubs on dry and exposed slopes, alt. up to 2,200 meters, El Picacho de Galipan, Distr. Fed., January 8, 1940 (Chi.).

French Guiana: Mélinon, Maroni, 1877 (Chi.).

Brazil:Blanchet 657, vicinity of Bahia, 1831 (N.Y.); H. M.Curran 631, Nova Friburgo, State of Rio de Janeiro, December 9, 1918 (Chi.; N.Y.); Francis Drouet 2507, shrub up to 2 meters tall, on upper beaches, Barro do Ceará, Municipio de Fortalya, State of Ceará, September 25, 1935 (Chi.; Gray; N.Y.); George Gardner 5978, Brazil, 1836-1841 (N.Y.); Martius 397, Brazil (Gray; N.Y.).

Bolivia: Otto Kuntze, alt. 2,000 meters, Tunari Mountains, April, 1892 (N.Y.).

Bermuda: J. W. Harshberger, limestone sinks, Walsingham, June 16, 1905 (Gray; U.S.).

Cuba: N.L.Britton 2145, sand dunes, Conde Beach, Guantanamo Bay, Prov. Oriente, March 17-30, 1909 (N.Y.; U.S.); N. L. \& 
E. G. Britton \& J. F. Cowell 12493, coastal thicket, Punta Piedra, Nipe Bay, Prov. Oriente, March 7, 1912 (Chi.; N.Y.; U.S.); C. Wright 2173, sea-shore, Cuba, 1860-1864 (Gray).

Haiti: H. H. Bartlett 17432, small tree, Bayeaux, June 16, 1941 (U.S.); E. L. Ekman 2603, on the beach, November 21, 1924 (N.Y.); Emery C. \& Genevieve M. Leonard 13812, shrub 5 feet tall, on beach of Bord de Mer, vicinity of Jean Rabel, March 11, 1929 (Gray; U.S.); Leonard \& Leonard 15351, shrub 5 feet tall, beach west of harbor, vicinity of La Vallee, Tortue Island, May 4, 1929 (N.Y.; U.S.); George V. Nash 149, small tree, along shore, Bayeux, near Port Margot, August 5, 1903 (Chi.; N.Y.).

Santo Domingo: W. L. Abbott 2564, small tree, near sea level, Jovero, February 1-7, 1923 (U.S.); Eggers 2609, in fruticetis maritimis at Puerto Plata, June 22, 1887 (N.Y.; U.S.); James A. Faris 542, low tree, 8-12 feet tall, sandy beach, Isl. Santo Domingo, September, 1921 (U.S.); Miguel Fuertes 317, alt. 250 meters, Barahona, June, 1910 (Chi.; Gray; N.Y.; U.S., 2 sheets).

Puerto Rico: N.L. Britton \& J.F. Cowell 1543, shrub 2.5 meters tall, in coastal thicket, Cataño, February 14, 1914 (N.Y.; U.S.); Mary J.Fisher 17 (U.S.); A. A. Heller 4507, alt. 10 feet, along the beach, near Mayaguiez, February 3, 1900 (Chi.; Gray; N.Y.; U.S.); W. E. Hess \& F. L. Stevens 4886A, Boqueron, November 12, 1913 (N.Y.); Brother Hioram, Palo Seco, October, 1912 (N.Y.); J. R. Johnston 722, Mameyes, December 5, 1912 (N.Y.); J. I. Otero 448, Cabo Rojo, Distr. Bayamon, January 23, 1938 (Chi.); F. H. Sargent A28, shrub, on beach, Mayagüez, May 22, 1937 (U.S.); P. Sintenis 108, sea-shore at Guanajibo, Mayagüez, October 27, 1884 (Gray; U.S.); F. L. Stevens 2434, Patillas, June 22, 1913 (N.Y.); J. A. Stevenson \& J. R. Johnston 1352, Cataño, February 19, 1914 (U.S.); L. M. Underwood \& R.F. Griggs 179, sandy sea-shore, June 20, 1901 (N.Y.; U.S.).

Jamaica: R. C. Alexander, Port Royal Mountains, April, 1850 (N.Y.); E. Campbell 6052, Port Henderson, August 23, 1895 (N.Y.); Mr. March 1335 (Gray).

Grand Cayman: Charles F. Millspaugh 1264, Georgetown, February 12-15, 1899 (Chi.).

St. Martin: I. Boldingh 2504, in 1906 (N.Y.).

Marie Galante: Père Duss 3627, on sands near sea's edge, between Saint Louis and Grand Bourg, April 19, 1895 (N.Y.; U.S.).

St. Thomas: Baron Eggers, along the shore, Longbay, August, 1880 (Gray); Eggers, July, 1881 (U.S.). 
Martinique: Père Duss 368, pretty shrub, sands at sea-shore, Diamant, 1880 (Chi.; N.Y.; U.S.).

Grenada: W. E. Broadway, small tree along sea-shore, February, 1905 (Chi.; Gray; N.Y.).

Trinidad: W. E. Broadway 8996, shrub at sea-shore, Icacos, December 3, 1929 (N.Y.).

Tanganyika Territory: H.J. Schlieben 4394, shrub or small tree, very frequent, lower edge of forest zone, alt. 1,800 meters, south side of Kilimanjaro, December 29, 1933 (Chi.); Stolz 82, Nyassa District, Kondeland, 1900 (Arn.).

Yunnan Province, China:G. Forrest 11234 (Arn.; Calif.); Camillo Schneider 2212, alt. circ. 2,800 meters, valley of Yangtze River near Taku toward Chungtien, August, 1914 (Arn.).

Philippine Islands: Adduru 8 pro parte, shrub 2 meters tall, at sea-shore, vicinity of Peñablanca, Cagayan Province, Luzon, May 1-June 18, 1917 (Chi.); E. B. Copeland 351, Davao, Distr. Davao, Mindanao, March, 1904 (N.Y.); P. Cortes \& M. D. Knapp (Forestry Bur. no.) 23946, Panay, Prov. Capiz, May and June, 1915 (Arn.); A. D. E. Elmer 10452, Cagayan, Distr. Cagayan, Mindanao, April, 1909 (Arn.); Elmer 10452a, same place and date (Chi.); Elmer 12179, Magallanes (Mount Giting-giting), Sibuyan, Prov. Capiz, April, 1910 (Arn.; Chi.; Gray); (distrib. of) Elmer 16760, Irosin, Trosin (Mount Bulusan), Prov. Sorsogon, Luzon, July, 1916 (Arn.; Calif.; Chi.); F. W. Foxworthy 629, Palawan, March \& April, 1906 (Gray; N.Y.); H. Hallier 231, years 1903 and 1904 (N.Y.); Elmer D. Merrill (species Blancoanae n.) 601, Tayabas Province, Luzon, March, 1914 (Chi.; N.Y.); Merrill 934, Caguray, Mindoro, April, 1903 (Gray; N.Y.); Merrill 2402, Pola, Mindoro, May, 1903 (N.Y.).

Guam:Guam Experiment Station 328 (N.Y.; U.S.); R.C. McGregor 460, October, 1911 (N.Y.; U.S.).

British North Borneo: Mail 3647, tree 21 feet tall, girth 12 inches, at Tg. Peras, native name tukil-tukil bini, September 17, 1933 (Arn.); D. D. Wood 1747, Balambangan Isl., May, 1923 (Arn.; Calif.).

Java: Dr. Kollmann 1838 (N.Y.).

Molucca Islands: Hugo Curran 327, on beach, 5 meters tall, Manipa Isl., May 5, 1940 (Arn.); C. B. Robinson 1 (representing "Caryophyllaster litoreus," Rumphius Herb. Amboinense 4: 110, tab. 50), Amboina, July-November, 1913 (Gray; N.Y.; U.S.).

Papua (New Guinea): L. J. Brass 866, at coast, large bush or small tree, common along foreshores, Port Moresby, December 30, 
1925 (Arn.); Brass 1612, common name lelechi, Bomgwina, January 6, 1926 (Arn., 2 sheets); Brass 4711, tree 3-4 meters tall, alt. 2,840 meters, Murray Pass, Wharton Range, Central Division, JuneSeptember, 1933 (Arn.; N.Y.); Brass 6418, tree 3-5 meters tall, coast between Oriomo and Fly rivers, March 31, 1936 (Arn.); Brass 11397, sometimes in pure stands, up to 20 meters tall, trunk diameter up to 0.4 meter, alt. 2,200 meters, Bele River, $18 \mathrm{~km}$. northeast of Lake Dabbuna, Dutch New Guinea, November, 1938 (Arn.; apparently a race or subforma of $\mathrm{f}$. repanda growing to a colossal size and with leaves approaching some of those on Brass's material of f. Schiedeana); Clemens 5626, alt. 9,000 feet, Morobe Distr., March, 1937 (Arn.).

Bismarck Archipelago: J. H. L. Waterhouse 327, Gazelle Peninsula, October, 1934 (N.Y.).

Solomon Islands: S. F. Kajewski 2458, native name ingele, small tree up to 5 meters tall, at sea-level, in rain-forest, Berande, Guadalcanal Isl., January 16, 1931 (Arn.).

New Hebrides: S. F. Kajewski 120, shrub circ. 2 meters tall, in rain-forest, alt. 150 meters, Lenakel, Tanna Isl., June 3, 1928 (Arn.; N.Y.).

New Caledonia: Balansa 157, years 1868-1870 (Arn.); Balansa 2268, years 1868-1870 (Arn.); I. Franc, Prony (Arn.; U.S.).

Fiji Islands: A. C. Smith 1284, slender tree 3 meters tall, native name usi, Kambara, March 2-7, 1934 (Calif.; Gray; N.Y.; U.S.).

Samoa: Erling Christophersen \& E. P. Hume 2364, alt. \pm 100 meters, shrub 1.5 meters tall, Manase Plantation, Isl. Savali, August 13, 1931 (Calif.; N.Y.); Dr. Reinecke 356, Savaii Isl., June, 1894 (U.S.); United States Exploring Expedition (U.S.); F. Vaupel 293, above Manase, June 23, 1905 (U.S.).

Society Islands: United States Exploring Expedition, 1838-1842 (N.Y.); U. S. Explor. Exped., Isl. Tahiti (Gray; U.S.).

Australia: C. E. Hubbard 3478, in white sand, Hercules Bank, mouth of Brisbane River, Queensland, July 28, 1930 (Arn.); Hubbard 4448, on sand hills, Fraser Isl., Queensland, October 10-15, 1930 (Arn.); J. H. Maiden \& J. L. Boorman, Norfolk Isl., New South Wales, November, 1902 (Gray); Rev. N. Michael 138, Flying-fish Point, North Queensland (Gray); C. T. White 6906, Hercules Bank, mouth of Brisbane River, July 27, 1930 (Arn.; N.Y.).

Specimens examined for f. 2. Schiedeana (Schlecht.) Radlk.:1

${ }^{1}$ Radlkofer (op. cit. 647) cites also the states of Bahia, Rio de Janeiro, and São Paulo, Brazil, for f. Schiedeana. 
Mexico: $G$. Bossé 8370, at Lago Coapilla and on road to Santa Rita, State of Chiapas, January 18, 1926 (Chi.); George L. Fisher 35441, tree 20 feet tall, alt. 2,306 meters, Tepoztlan, State of Morelos, July 14, 1935 (Chi.; N.Y.); T. C. Frye \& E. M. Frye 3132, growing 6-12 feet tall, about $5 \mathrm{~km}$. north of Taxco, State of Guerrero, January 17, 1941 (Calif.); George B. Hinton 4869, shrub 1.5-5 meters tall, native name chapulixtle, alt. 2,400 meters, Cajones la Angostura, Distr. of Temascaltepec, State of Mexico (Chi.); Hinton et alii 8974, shrub 4 meters tall, in lower oak belt, on hill, Rincón, same district, March 11, 1936 (Gray); Liebmann 2193, Rio de las Vueltas, May, 1842 (Chi.); L. H. MacDaniels 300, shrub 6-8 feet tall, alt. 5,500 feet, in fields along the Mexico City-Cuernavaca Road near Cuernavaca, State of Morelos, August 28, 1935 (Chi.); E. W. Nelson 6955, Volcán de Jorullo, State of Michoacán, March, 1903 (Gray); J. N. Rose \& Joseph H. Painter 6955, Cuernavaca, September, 1903 (N.Y.); Rose, Painter, \& J. S. Rose 8797 p. p., Pachuca, State of Hidalgo, July, 1905 (Chi.; Gray); Caec. \& Ed. Seler 403, near Hochi, Distr. Cuernavaca, State of Morelos, December, 1887 (Gray); Seler \& Seler 649, near Huejutla, State of Hidalgo, May, 1888 (Gray); Seler \& Seler 4253, mountain slope, Distr. Hidalgo, State of Guerrero, May 18, 1904 (Gray); Seler \& Seler 4435, Hacienda de Los Arcos, Zultepec, December 20, 1904 (Gray); G. Woronow 2823, Rio Zumpimito near Uruapan, State of Michoacán, January 21, 1926 (Chi.).

British Honduras: Percy H. Gentle 1775, Sibun River, Yucatan Peninsula, January 10, 1936 (N.Y.).

Guatemala: W. A. Kellerman 7627, alt. 1,500 feet, San Augustine, Sierra de las Minas, Dept. Baja Verapaz, January 12, 1908 (Chi.); Julian Steyermark 31292, shrub 20 feet tall, on dry, rocky glade slopes, alt. 1,200-1,500 meters, 3 miles southeast of Quezaltepeque, along Río Lucía Saso, vicinity of Montaña Cebollas, Montaña Castilla, Dept. Chiquimula, November 6, 1939 (Chi.).

Peru: J. Soukup 782, January, 1938 (Chi.).

Bolivia: R. S. Williams 190 p. p., bush, alt. 4,800 feet, Apolo, July 20, 1902 (N.Y.).

Isle of Pines (West Indies): A. H. Curtiss 263, near Nueva Gerona, January 1-February 4, 1904 (Chi.; Gray; N.Y., 2 sheets; U.S.).

British East India: A. Saulière 40, Kodaikanal Station, Pulney Hills, Madura District, Presidency of Madras, 1914 (N.Y.).

Timor: Boscharchitect Koepang 16, alt. 1,300 meters, April 10, 1935 (Arn.). 
Papua (New Guinea): L. J. Brass 5053, tree 3-6 meters tall, alt. 2,400 meters, May-September, 1933 (Arn.; N.Y.); M. S. Clemens 475, in open woods, 10 feet tall, alt. 2,500 feet; on hills, below Sattelberg, Morobe District, October 17, 1935 (Arn.); Clemens 4745, in open woods, alt. 5,000-5,500 feet, vicinity of Ogeramnang, Morobe District, December 24, 1936 (Arn.); R. Schlechter 19118, woods in Tinisterre District, Kaiser-Wilhelmsland, January 17, 1909 (Arn.; Chi.; U.S.).

Specimens examined for f. 3. Burmanniana (Schum. \& Thonn.) Radlk.:

Mexico: H. H. Bartlett 10737, La Morita, vicinity of Marmolejo, Sierra de San Carlos, State of Tamaulipas, August 1, 1930 (Chi.; Gray); Mary Taylor Edwards 736, Jacala, State of Hidalgo, August 11, 1937 (Chi.); G. M. Emrick 109, Ostula, State of Michoacán, November, 1906 (Chi.); Emrick 214, Hacienda Coahuayula, State of Michoacán, February, 1901 (Chi.); Dwight R. Furness, Guanajuato (Chi.); Howard Scott Gentry 4276, slender shrub 1-3 meters tall, on open, rocky hill-slopes, in oak forest, alt. 4,000-5,000 feet, Cerro de la Giganta, Baja California, March 1, 1939 (Gray); George B. Hinton 295, shrub, Rincón, Distr. Temascaltepec, State of Mexico, February 22, 1932 (Gray); Hinton 10307, shrub 3 meters tall, San Antonio, Distr. Montes de Oca, State of Guerrero, 1937 (Chi.; N.Y.); Hinton et alii 11712, shrub 3 meters tall, on hill, San Antonio, same district, December 23, 1937 (Gray); E. W. Nelson 6087, Cerro la Silla, near Monterey, State of Nuevo León, March 20, 1902 (N.Y.); Nelson 6955, shrub 6-12 feet tall, Volcano Jorullo, State of Michoacán, March 28, 1903 (Gray); Brother Nicolás, Noria, State of Puebla, February (Chi.); Nicolás 5711, precise locality not stated, but collected somewhere in same state, i.e., Puebla, December 15, 1910 (N.Y.); Cyrus Guernsey Pringle 3461, San José Pass, State of San Luis Potosí, July 23, 1890 (Chi.); J. N. Rose 2406, near San Juan Capistrano, State of Zacatecas, August, 1897 (Gray; N.Y.); J. N. Rose, Joseph H. Painter, \& J. S. Rose 8797 p. p., Pachuca, State of Hidalgo, July, 1905 (N.Y.); H. W. Von Rozynski 282, near Nogales, Jaumave, State of Tamaulipas, 1932 (Chi.; N.Y.); Von Rozynski 398, Jaumave, July, 1932 (Chi.; N.Y.); Von Rozynski 706, sierra near Victoria, Jaumave, 1932 (N.Y.); H. H. Rusby 110, State of Oaxaca, July 16, 1910 (N.Y.); Caec. \& Ed. Seler 45, near Fortaleza de Mitla, Distr. Tlacolula, State of Oaxaca, June, 1888 (Gray); Seler \& Seler 1525, above El Porian to the lower slopes of Cuauhtlillo, State of Oaxaca, November 27 and 28, 1895 (Gray, 
where determined for this forma by Radlkofer); Charles $L$. Smith 824, alt. 5,500-6,000 feet, Monte Alban, near Oaxaca City, State of Oaxaca, September 5, 1894 (N.Y.); Rev. Lucius C. Smith 864, alt. 6,500-7,000 feet, hills of Telixtlahuaca, State of Oaxaca, October 18, 1895 (Gray).

British Honduras: H. H. Bartlett 11291, shrub 8 feet tall, on pine ridge, Cornhouse Creek, Manatee River, Belize District, January 31, 1931 (N.Y.).

Guatemala: W. A. Kellerman 7480, Los Amatos, Dept. Izabal, February 15, 1908 (Chi.; N.Y.); Alexander F. Skutch 1005 p. p., alt. 6,800 feet, San Miguel Acatan, Dept. Huehuetenango, August 18, 1934 (N.Y.); Paul C. Standley 62579, shrub 4-6 feet tall, abundant, in pine and oak forest, alt. circ. 1,800 meters, near Chalchitán, same department, January 14, 1939 (Chi.); Standley 62610, shrub 3-4 feet tall, common, in oak and pine forest, alt. 1,800-2,400 meters, mountains southwest of Malacatancito, same department and date (Chi.); Standley 65657, shrub 3-5 feet tall, abundant at 7,000 feet, on dry, rocky hillside, Sierra de los Cuchamatanes, above Chiantla, same department, February 19, 1939 (Chi.); Julian A. Steyermark 38305, shrub 5-8 feet tall, alt. 80-83 meters, in sand along Motagua River, between Los Amates and Quiriguá, Dept. Izabal, March 29, 1940 (Chi.).

Costa Rica: H.E. Stork 3158, shrub 15-20 feet tall, in open, oak forest, alt. 5,800 feet, vicinity of Santa María de Dota, San José, July 8, 1932 (Chi.); Manuel Valerio 1364, alt. 1,550 meters, Santa María de Dota, December 30, 1935 (Chi.).

Panama: M.E. Terry 1259, shrub 12-15 feet tall, alt. 5,500 feet, Salta, Boquete, Boquete District, Chiriqui Prov., January 8, 1939 (Chi.).

Colombia: Ellsworth P. Killip 11269 p. p., shrub, Restrepo, Cordillera Occidental, Dept. El Valle, September 16, 1922 (Gray; N.Y.); Killip \& Albert C. Smith 19765 p. p., shrub 2-5 feet tall, on open hillside, alt. 2,700-3,400 meters, between Mutiscua and Pamplona, Dept. Norte de Santander, February 23, 1927 (Gray); Francis $W$. Pennell 1839, shrub, alt. 1,500-1,600 meters, on open slope, along road below Caqueza, Dept. Cundinamarca, September 7 and 8, 1917 (N.Y.).

Ecuador: F. C. Lehmann 4800, Oña, Cuenca (Chi.; at Gray commixed with var. arborescens f. spatulata); Ynes Mexia 7047, spreading shrub, common, 1 meter tall, native name chamana, on open river terrace, alt. 1,200-1,500 meters, near Banos, March 6, 1935 (Chi.). 
Peru: Sawada P. 120, San Rafael, Huanuco, October 28, 1927 (Chi.); H. E. Stork \& O. B. Horton 10413, shrub, very common, called chamana, used as mattresses for beds, the gum sticking the twigs firmly together so that they make a solid unit, alt. 1,200-2,700 meters, Surcubamba-Salcabamba Trail, Prov. Tayacaja, Dept. Huancavelica, January 14, 1939 (Calif.; Chi.); Stork \& Horton 10784, very common, sometimes a tree 4 meters tall, alt. from 2,500 down to 2,000 meters, at confluence of Río Chincheros and Río Pampas, Prov. Andahuaylas, Dept. Apurimac, March 1, 1939 (Calif.; Chi.).

Venezuela: A. Fendler 2545, near Tovar Colony, 1856-1857 (Gray); Llewelyn Williams 10107, shrub or small, slender tree, abundant on dry, open slopes, alt. 1,530 meters, Avila, Distr. Fed., May 19, 1938 (Chi., 2 sheets; approaching f. Schiedeana).

Brazil: H. M. Curran 631, Nova Friburgo, State of Río de Janeiro, December 9, 1918 (Gray); A. Glaziou 52, shrub, region of Copacabana, same state, March 14, 1862 (N.Y.); Glaziou 14580, shrub, State of Minas Geraes, December 16, 1884 (N.Y.); Sello 159 (Gray); Weddel 131 p. p., environs of Río de Janeiro, State of Río de Janeiro, 1843 (N.Y.).

Bolivia: Otto Buchtien 531, shrub or tree, alt. 2,100 meters, November 20, 1906 (N.Y.); José Steinbach 8602 p. p., alt. 2,800 meters, Comarapa, Dept. Santa Cruz, November 1, 1928 (Chi.).

Chile: Guillermo Geisse, Tulahuen (Ovalle), 1889 (Gray).

Argentina: W.J.Eyerdam \& A. A. Beetle 22674, tree 8-10 meters tall, in sand and gravel along stream bank, in shade of forest, alt. 600 meters, Arroyo La Cantara, Cerro de Calilegua, Prov. Jujuy, October 19, 1938 (Calif.; Gray); Eyerdam, Beetle, \& E. Grondona 23634, shrub 1-1.5 meters tall, in alluvial deposit on high, exposed cliffs, alt. 50 meters, Cerro La Peregrina, Prov. Buenos Aires, December 11, 1938 (Calif.; Gray); P. G. Lorentz \& G. Hieronymus 1187, in the sierra between El Rincon and Clavisan, river district of Río del Tala, Prov. de Salta, December 11, 1873 (N.Y.); S. Venturi 2233, shrub 2-3 meters tall, alt. 500 meters, at edge of river gorge, Dept. Cruz Alta, Prov. Tucumán, October 12, 1923 (Calif.; Chi.; Gray); Venturi 9473, shrub 3 meters tall, alt. 900 meters, Sierra de la Candelaria, Dept. Candelaria, Prov. de Salta, September 15, 1929 (Gray; N.Y.).

Uruguay: W. G. Herter 5049, in dry, exposed, clay soil, alt. 200 meters, Sierra Animas, Dept. Maldonado, September, 1929 (Gray). 
Abyssinia: $W$. Schimper 705, in mountains near Dscheladscheranne, native name dasos, November 3, 1839 (N.Y.).

Kenya Colony: Edgar A. Mearns 387 p. p., alt. circ. 2,000 meters, between Oljoro-o-Nyon and Narok rivers, June 7 and 8, 1909 (N.Y.).

Tanganyika Territory: H. J. Schlieben 3609, shrub 2-4 meters tall, alt. 1,400 meters, savanna hills, Uluguri Range, Morogoro District, February 27, 1933 (Arn.).

South Rhodesia: G. M. McGregor $M 73 / 37$, on Odzani River, Umtali District, May 23, 1937 (N.Y.).

Réunion: G. de l'Isle 566, shrub, in 1875 (Gray; U.S.).

China (see also Hainan below): George Forrest 11233, Yunnan (Arn.); Forrest 16868, Yunnan, 1917-1919 (Arn.); Maire 6291 (ser. $B$ ), among rocks, alt. 3,200 meters, Mea hong, Yunnan, August, 1910 (N.Y.); Peter Siméon Ten 184, erect shrub, 1.5 meters tall, near tie so bridge, vicinity of Pe Yen Tsin, northwestern Yunnan, June 18, 1916 (Arn.).

Hainan: Chun \& Tso 44503, shrub 2 meters tall, in forest, Yaichow, December, 1932-1933 (Arn.; Chi.; N.Y.); Chun \& Tso 44637, shrub 2 meters tall, on open slope, alt. 100 feet, Yaichow, December, 1932-1933 (Chi.; N.Y.); S. P. Ko, shrub 3 meters tall, in woods, Po-ting to Seven Finger Mountain, Lingshin, April 23, 1932 (Chi.; N.Y.); S. K. Lau 74, fairly common, 1.5 meters tall, in thicket, sandy soil, $2 \mathrm{~cm}$. diam., Yeung Ling Shan, Ngai District, June 13, 1932 (Arn.; Calif.; N.Y.); Lau 1003, fairly common, on dry, level land, in clay meadow, 1 meter tall, Nodoa and vicinity, Tan District, February 3, 1933 (Arn.; N.Y.); Lau 3383, abundant on dry, gentle slope, sandy soil at roadside, erect, 3 meters tall and $6 \mathrm{~cm}$. diam., Chim Fung Ling near Sam Mo Watt village, Kan-en District, March 8, 1934 (Arn.); C. I. Lei 396, shrubs, abundant, on dry, level land, sandy soil, roadside thicket, Woh Ham Shi and vicinity, Lam Ko District, February 23, 1933 (Calif.; N.Y.); H. Y. Liang 62898, shrub 2 meters tall, in open thickets, sandy places near seashore, Yaichow, Kwangtung, September 5, 1933 (N.Y.); Liang 65071, shrub 1 meter tall, on open slopes, at Hainan, February 21, 1934 (N.Y.); Liang 65348, shrub 2 meters tall, in thicket, same locality, February 27, 1934 (N.Y.); Liang 66009, shrub 2 meters tall, same locality, December 10, 1933 (N.Y.); C. Wang 32893, small shrub on mountain top, Kwangtung, July 8, 1933 (N.Y.); Wang 36485, small shrub, at Hainan, January 12, 1934 (N.Y.).

Indo-China: J. \& M. S. Clemens 3210 p. p., common dune shrub, Tourane (Turan) and vicinity, Annam (Anam), May-July, 1927 
(Arn.); A. Pételot 6259, Prov. of Vinh, Annam, April, 1936 (Arn.); C.B. Robinson 1094, Nha-trang and vicinity, Annam, March 11-26, 1911 (N.Y.).

\section{Malaya: A. C. Maingay 459/2 (Gray).}

British East India: Father Anglade, alt. 1,000-8,000 feet, Kodaikanal region, Pulney Hills, southern India (Arn.); R. D. Anstead 104, very common shrub "covering all the hilltops in South India," alt. 6,000 feet, Kotagiri, Nilgiri Hills, April, 1923 (Arn.); Dr. Prain, Coonoor, Nilgiri, February 11, 1899 (Arn.); R. Wight, exceedingly common in inland parts of the country, many expansive tracts of country being completely covered with it, Mysore (Kew);E. $H$. Wilson, bush 6-12 feet tall, in open country, Ootacamund, October 14, 1921 (Arn., 2 sheets).

Ceylon: Thwaites 1158 (Calif.; Gray).

Philippine Islands: $M$. Adduru 8 pro parte, shrub 2 meters tall, vicinity of Peñablanca, Cagayan Prov., Luzon, June 29, 1917 (Arn.; elsewhere, e.g. Chi., material under this number is referable to f. repanda).

Java: Blume, in garden (N.Y.).

Papua (New Guinea): L. J. Brass \& Chr. Versteegh 10494, rare tree of secondary forest, 10 meters tall, trunk $31 \mathrm{~cm}$. diam., crown fairly small, bark $1 \mathrm{~mm}$. thick, alt. $\pm 2,600$ meters, $9 \mathrm{~km}$. northeast of Lake Habbema, Dutch New Guinea, October, 1938 (Arn.; approaching f. Schiedeana); C. E. Lane Poole 419, on grass lands and old farm lands near Menari, alt. 5,000 feet, February, 1923 (Arn.).

Fiji Islands: Otto Degener 14299, shrub 5-7 feet tall, in open, scrubby forest, alt. 2,500 feet, Nandarivatu, Tholo North, Viti Levu, February 9, 1941 (Arn.); Degener 14332, shrub 5 feet tall, in scrub, alt. 2,500 feet, native name osi, same locality, February 13, 1941 (Arn.); Degener \& Ordoñez 13537, shrub 5 feet tall, in scrub, alt. 2,600 feet, Nandarivatu, November 20, 1940 (Arn.); Degener \& Ordoñez 13703, shrub 4-5 feet tall, alt. 30 meters, in scrub, Rakiraki, Viti Levu, December 13, 1940 (Arn.); Degener \& Ordoñez 13710, shrub 5 feet tall, in scrub, alt. 400 feet, northwest gulch of small, jagged range north of Lomolomo, Lautoka, Viti Levu, December 5, 1940 (Arn.); W. H. Harvey, November, 1855 (Gray); Albert C. Smith 826 p. p., tree 4 meters tall, on exposed cliff head, alt. 150-350 meters, hills west of Mbutha Bay, Natewa Peninsula, Vanua Levu, December 21, 1933, native name wosi (Gray; U.S.).

Australia: F. T. Freney, Cooper's Plains, near Brisbane, Queensland, November, 1920 (Arn.); Sabine Helms 940, shrub on dune, 
peninsula north of "The Entrance," Tuggerah via Wyong, New South Wales, 1922 (Arn.); C. T. White 1849, Burleigh Heads, southeast Queensland, November, 1921 (Arn.); White 6349, Traverston, mouth of Burru River, Queensland, 1929 (Calif.).

Dodonaea viscosa var. a vulgaris $f$. 4 . eriocarpoidea $f$. nov.Ramuli ultimi hispiduli. Folia circumambitu variabilia (pro typo anguste elliptico- vel oblongo-lanceolata, utrinque acuminata, graciliter petiolata, minutissime ciliolata, $5-10.5 \mathrm{~cm}$. longa et 0.8 $1.7 \mathrm{~cm}$. lata), saepe eis f. Burmannianae vel f. angustifoliae rarius eis f. spatulatae subsimilia. Inflorescentiae plus minusve hispidulae, masculinae plerumque numerosae parvae densae 1-2 cm. longae.

Ultimate branchlets hispidulous. Leaves variable in outline (those on the type narrowly elliptic- or oblong-lanceolate, at both ends acuminate, slenderly petioled, very minutely ciliolate, 5-10.5 $\mathrm{cm}$. long and 0.8-1.7 cm. wide), often subsimilar to those of $\mathrm{f}$. Burmanniana or of f. angustifolia or more rarely to those of $\mathrm{f}$. spatulata. Inflorescences more or less hispidulous; staminate ones commonly numerous, small, dense, $1-2 \mathrm{~cm}$. long.

Specimens examined:

Mexico: G. Andrieux 488, Mitla, near Oaxaca, July (Gray); Berlandier 929, in mountains near San Carlos, November, 1831 (Gray; N.Y.); Berlandier 2359, same place and date (Gray; N.Y.);Bourgeau 312, Santa Fé, Valley of Mexico, July 26, 1865 (Gray); V. H. Chase 7156 , shrub 8 feet tall, north of Jacala, State of Hidalgo, June 26, 1939 (Calif.); Hartweg 19, Mexico (Gray); Ivan M. Johnston 3849, shrub 5-7 feet tall, dense, infrequent, on gravelly plain, Puerto Escondido, Baja California, May 24, 1921 (Calif.; Chi.; Gray; N.Y.); Nelson \& Goldman 7154, shrub 10-15 feet tall, alt. 2,000 feet, Yubai, Baja California, September 18, 1905 (Calif.); Charles R. Orcutt 3297, Veracruz, February 16, 1910 (Chi.; Gray); Edward Palmer 127 and 181, Nuevo León, February and March, 1880 (Gray; N.Y.); C. C. Parry \& Ed. Palmer 96, Mexico, 1878 (Gray); C. A. Purpus 3169, vicinity of San Luis Tultitlanapa, Puebla, near Oaxaca, May-July, 1908 (Calif.; Chi.; Gray; N.Y.); J.G. Schaffner 306, San Luis Potosí, 1879 (Calif., leaves approaching or passing into those of var. linearis f. arizonica; N.Y.); Schaffner 709, in mountains, San Miguelito, San Luis Potosí Valley, 1876 (type, Chi.); Walther Schumann 471, in mountains, Jaral, May 26, 1885 (Chi.; Gray); Stephen S. White 1647, low shrub, alt. about 2,500 feet, Cerro de la Silla, near Monterey, Nuevo León, June 30, 1939 (Gray). 
In its strong tendency toward pubescence in the inflorescences and on the leaf-edges, this forma suggests var. linearis f. arizonica, to which it is indeed close. The leaves are mostly broader than in that forma, however, and when fairly large, as on the type, suggest small-leaved f. Burmanniana material. Some specimens have shorter leaves, these more spatulate and apically less acuminate to obtuse. Orcutt 3297, Nelson \& Goldman 7154, and Johnston 3849 are such specimens. ${ }^{1}$ Forma eriocarpoidea offers at times a resemblance to Dodonaea eriocarpa Smith and some of the many varieties, mostly Hawaiian, of that species. Its geographic range, as far as known, extends from the northern border of the State of Oaxaca northward along the eastern part of Mexico, but must include the somewhat remote localities farther west, cited for Baja California. In this latter region occur additional specimens that appear to constitute a new forma referable to a place next to f. Ehrenbergii under var. arborescens (and described below as f. hispidula).

Dodonaea viscosa var. $\beta$ linearis (Harv. \& Sond.) Sherff, Amer. Journ. Bot. 32: 214. 1945 et f. linearis Sherff loc. cit. Dodonaea linearifolia Linden Pl. Cub. num. 2070 (annis 1841-1846) et apud Turcz. Bull. Mosc. $31^{\mathrm{I}}$ : 407. 1858. Dodonaea linearis E. Mey. in Hb. Drège, Flora 26 ${ }^{\text {II }}$, Beigabe p. 179. 1843. Dodonaea Thunbergiana var. linearis Harv. \& Sond. Fl. Cap. 1: 242, sub num. 2. 1859-1860.

Dodonaea viscosa has, in addition to the var. vulgaris $\mathrm{f}$. eriocarpoidea just described, three more or less easily recognizable formae with proportionately narrower or more elongate leaves than is usually the case in such varieties as var. vulgaris and var. arborescens. These forms have been referred rather commonly to var. angustifolia Benth., mentioned above as having been retained by Radlkofer for certain Brazilian material. However, Bentham's epithet, published in 1863 , was antedated for varietal status by var. linearis Harv. \& Sond., published at least three years earlier.

Typical var. linearis, which may be designated (in the sense of a forma) as f. linearis, is found in South Africa, the West Indies (islands of Cuba and Haiti), northwestern Mexico, etc. It has linear leaves, these short $( \pm 5 \mathrm{~cm}$.) or long $( \pm 7-11 \mathrm{~cm}$.). Its inflorescence has the branchlets glabrous to sparsely setulose; otherwise it might be mistaken in many cases for f. arizonica (vide infra).

${ }^{1}$ It must be pointed out that the assignment of $\mathrm{f}$. eriocarpoidea to var. vulgaris is arbitrary. It might with almost equal reason be made to var. linearis or to var. arborescens. 
Specimens examined for f. 1. linearis:

Mexico: Roxana S. Ferris 8807 , dominant shrub on slopes above flat, cultivated river valley, 2 miles north of Imuris on Nogales Highway, State of Sonora, March 24, 1934 (N.Y.); H. S. Gentry 1120, shrub 5 or 6 feet tall, in arroyo, Conejos, Río Mayo, State of Sonora, October 26, 1934 (Chi.);E. A. Goldman 230, near Batopilas, State of Chihuahua, October 8, 1898 (N.Y.); C. V. Hartman 84, shrub 6-12 feet tall, alt. 5,100 feet, Cochuto, State of Sonora, October 4, 1890 (N.Y.); Hartman 204, shrub 4-8 feet tall, alt. 3,450 feet, Oputo, State of Sonora, November 1, 1890 (Gray); Ivan M. Johnston 4319, erect shrub, single plant under palm, San Pedro Bay, State of Sonora, July 7, 1921 (Calif.; Chi.; Gray; N.Y.); I. Knobloch 5627, Mojarachic, State of Chihuahua, October 23, 1938 (Chi.); Harde LeSueur, Río Bonito, State of Chihuahua, August 25, 1936 (Chi.); Edward Palmer 143, Hacienda San Miguel, near Batopilas, State of Chihuahua, September, 1885 (Gray; N.Y.); Palmer 247, alt. 7,000 feet, mountains above Batopilas, November, 1885 (Gray); Forrest Shreve 6646, at 11 miles west of Cucurpe, State of Sonora, September 13, 1934 (Gray); Rose, Standley, \& Russell 12804, Sierra de Alamos, State of Sonora, March 14, 1910 (Gray; N.Y.); Stephen S. White 400, shrub, about 5 miles north of Montezuma, State of Sonora, July 1, 1938 (Gray); White 514, small, slender shrub, Santa Rosa Canyon, near Bavispe, State of Sonora, July 15, 1938 (Gray); Ira L. Wiggins 6480 , main canyon east of La Palma, 50 miles north of Guaymas, in Sierra Libres, State of Sonora, March 9, 1933 (Calif.; Chi.; N.Y.).

Ecuador: A. Rimbach 612 p. p., small shrub on dry hills, alt. 2,700 meters, interandine highland near Riobamba (N.Y.).

Cuba: Eugenio Cuesta 1079, Prov. Pinar del Río, April, 1915 (N.Y.); Linden 2070 (Gray, type collection of Dodonaea linearifolia Linden apud Turcz.); C. Wright 3525, in 1865 (Gray).

Haiti: L. R. Holdridge 1009, tree about 4 meters tall, alt. 350 meters, Port au Prince, February 18, 1942 (U.S.);E. C. Leonard 8967, slender shrub about 12 feet tall, in dry thicket on slopes, alt. 325-900 meters, south of Ennery, Dept. L'Artibonite, January 19, 1926 (Calif.; Gray; N.Y.; U.S.); Leonard 8985, slender shrub up to 12 feet tall, in dry, rocky thicket near summit of mountain southeast of Ennery, January 19, 1926 (U.S.).

South Africa: Dr. Burchell 4900 (Gray); J. F. Drège, in 1843 (N.Y.); Drège 7532a (Gray; N.Y.); L. M. Kapp, native name 
untain slopes near Uniondale, District of Uniondale, 1921 (Arn.); Otto Kuntze, alt. 300 meters, Cogve Colony, February 2, 1894 (N.Y.); Macowan 717, feet, on slopes of Nieuwe Kloof Mountains, near ber, 1886 (Gray); F. A. Rogers 30100, alt. 1,800 feet, Distr. Albany (Arn.); W. A. \& C.B. Setchell, "Eistenbeyond Montague Pass on way to Oudtshoorn, Cape 11, 1927 (Calif.); J. Thode A1101, Enon, Cape lber, 1926 (N.Y.).

de l'Isle 627, Mount St. Denis, 1875 (Gray).

bbé Urbain Faurie 48, on Mount Taitum, June 30, . Henry, Takow (N.Y., 2 sheets); Playfair 97 (Arn.); 0975, by seashore, abundant, Bonjo to Kuram, Prov. nber 14, 1918 (Arn.).

. L. Boorman, Baan Baa, New South Wales, Novemf.); Fraser, New South Wales, 1818 (Arn., 2 sheets); Mount Warrah, New South Wales, October, 1897 hite 1720, Silverwood near Warwick, East Queensland, 2 (Arn.; Calif.).

viscosa var. $\beta$ linearis f. 2 . angustifolia (Benth.) Journ. Bot. 32: 214. 1945. Dodonaea angustifolia L. $f$. Syst. Veg. 218. 1781. Dodonaea angustifolia Swartz, 150. 1791. Dodonaea viscosa var. angustifolia Benth. 476. 1863.

iscosa var. angustifolia Benth. was founded upon $D$. artz (Observ. Bot. 150. 1791), a plant inhabiting ores Jamaicae" (fide Swartzii). But the younger already described (loc. cit.) a Dodonaea angustifolia India. With both Linnaeus $(f$.$) and Swartz, the$ aceolato-linearia." The two concepts were undoubtand have been so regarded by numerous authors. tz's name was of course a homonym and, under the Rules (edit. 3, art. 61. 1935), was illegitimate. ${ }^{1}$ For ble reasons, some American authors have rejected ustifolia, no matter for what status it was used by ent to Swartz. It must be observed here, however,

ay be "generally treated as a synonym on taxonomic grounds" - cit.) and still be a homonym. The essential requirement of a duplicates a name previously and validly published for a group ased "on a different type." 
Specimens examined for f. 1. linearis:

Mexico: Roxana S. Ferris 8807 , dominant shrub on slopes ah flat, cultivated river valley, 2 miles north of Imuris on Nog Highway, State of Sonora, March 24, 1934 (N.Y.); H. S. Ge 1120, shrub 5 or 6 feet tall, in arroyo, Conejos, Río Mayo, Stat Sonora, October 26, 1934 (Chi.); E. A. Goldman 230, near Batopi State of Chihuahua, October 8, 1898 (N.Y.); C. V. Hartman shrub 6-12 feet tall, alt. 5,100 feet, Cochuto, State of Son October 4, 1890 (N.Y.); Hartman 204, shrub 4-8 feet tall, alt. 3, feet, Oputo, State of Sonora, November 1, 1890 (Gray); Ivan Johnston 4319, erect shrub, single plant under palm, San Pedro B State of Sonora, July 7, 1921 (Calif.; Chi.; Gray; N.Y.); I. Knobl 5627, Mojarachic, State of Chihuahua, October 23, 1938 (Ch Harde LeSueur, Río Bonito, State of Chihuahua, August 25, 1! (Chi.); Edward Palmer 143, Hacienda San Miguel, near Batopil State of Chihuahua, September, 1885 (Gray; N.Y.); Palmer 2 alt. 7,000 feet, mountains above Batopilas, November, 1885 (Gra Forrest Shreve 6646, at 11 miles west of Cucurpe, State of Sono September 13, 1934 (Gray); Rose, Standley, \& Russell 12804, Sie de Alamos, State of Sonora, March 14, 1910 (Gray; N.Y.); Stephen White 400 , shrub, about 5 miles north of Montezuma, State of Sono July 1, 1938 (Gray); White 514, small, slender shrub, Santa Rc Canyon, near Bavispe, State of Sonora, July 15, 1938 (Gray); ] L. Wiggins 6480, main canyon east of La Palma, 50 miles north Guaymas, in Sierra Libres, State of Sonora, March 9, 1933 (Cal Chi.; N.Y.).

Ecuador: A. Rimbach 612 p. p., small shrub on dry hills, alt. 2,7 meters, interandine highland near Riobamba (N.Y.).

Cuba: Eugenio Cuesta 1079, Prov. Pinar del Río, April, 19 (N.Y.); Linden 2070 (Gray, type collection of Dodonaea linearifo Linden apud Turcz.); C. Wright 3525, in 1865 (Gray).

Haiti: L. R. Holdridge 1009, tree about 4 meters tall, alt. 3 meters, Port au Prince, February 18, 1942 (U.S.);E. C. Leonard 89 slender shrub about 12 feet tall, in dry thicket on slopes, alt. 325-9 meters, south of Ennery, Dept. L'Artibonite, January 19, 19 (Calif.; Gray; N.Y.; U.S.); Leonard 8985, slender shrub up to $12 \mathrm{fe}$ tall, in dry, rocky thicket near summit of mountain southeast Ennery, January 19, 1926 (U.S.).

South Africa: Dr. Burchell 4900 (Gray); J. F. Drège, in 18 (N.Y.); Drège $7532 a$ (Gray; N.Y.); L. M. Kapp, native nane 
Jjsterbosch, mountain slopes near Uniondale, District of Uniondale, Pretoria, July, 1921 (Arn.); Otto Kuntze, alt. 300 meters, Cogmanskloof, Cape Colony, February 2, 1894 (N.Y.); Macowan 717, alt. about 900 feet, on slopes of Nieuwe Kloof Mountains, near Tulbagh, October, 1886 (Gray); F. A. Rogers 30100, alt. 1,800 feet, Grahamstown, Distr. Albany (Arn.);W. A.\& C. B. Setchell, "Eistenbosh" Karroo, beyond Montague Pass on way to Oudtshoorn, Cape Province, May 11, 1927 (Calif.); J. Thode A1101, Enon, Cape Colony, November, 1926 (N.Y.).

Réunion: G. de l'Isle 627, Mount St. Denis, 1875 (Gray).

Formosa: Abbé Urbain Faurie 48, on Mount Taitum, June 30, 1903 (Arn.); A. Henry, Takow (N.Y., 2 sheets); Playfair 97 (Arn.); E. H. Wilson 10975, by seashore, abundant, Bonjo to Kuram, Prov. Koshun, November 14, 1918 (Arn.).

Australia: J.L. Boorman, Baan Baa, New South Wales, November, 1914 (Calif.); Fraser, New South Wales, 1818 (Arn., 2 sheets); J. H. Maiden, Mount Warrah, New South Wales, October, 1897 (Arn.);C.T. White 1720, Silverwood near Warwick, East Queensland, September, 1922 (Arn.; Calif.).

Dodonaea viscosa var. $\beta$ linearis f. 2 . angustifolia (Benth.) Sherff, Amer. Journ. Bot. 32: 214. 1945. Dodonaea angustifolia L. $f$. Supplem. Pl. Syst. Veg. 218. 1781. Dodonaea angustifolia Swartz, Observ. Bot. 150. 1791. Dodonaea viscosa var. angustifolia Benth. Fl. Austral. 1: 476. 1863.

Dodonaea viscosa var. angustifolia Benth. was founded upon $D$. angustifolia Swartz (Observ. Bot. 150. 1791), a plant inhabiting "montes frigidiores Jamaicae" (fide Swartzii). But the younger Linnaeus had already described (loc. cit.) a Dodonaea angustifolia from southern India. With both Linnaeus $\left(f_{.}\right)$and Swartz, the leaves were "lanceolato-linearia." The two concepts were undoubtedly identical and have been so regarded by numerous authors. However, Swartz's name was of course a homonym and, under the International Rules (edit. 3, art. 61. 1935), was illegitimate. ${ }^{1}$ For this or comparable reasons, some American authors have rejected the epithet angustifolia, no matter for what status it was used by writers subsequent to Swartz. It must be observed here, however,

1 A homonym may be "generally treated as a synonym on taxonomic grounds" (Internat. Rules loc. cit.) and still be a homonym. The essential requirement of a homonym is that it duplicates a name previously and validly published for a group of the same rank based "on a different type." 
that under the same International Rules (art. 69, examples, sub Talino polyandro Hook.) the illegitimacy of the name angustifolia ${ }^{1}$ for the concept as held by Swartz does not invalidate its use by Bentham and subsequent workers for a varietal status. The combination Dodonaea viscosa var. angustifolia Benth., even though Bentham cited Swartz's specific binomial, "is treated, not as a new combination, but as a new name." No parenthetical citation of "Swartz" is called for, therefore, before "Benth."

Radlkofer, in his classical study of Dodonaea, retained the var. angustifolia Benth. under $D$. viscosa and redescribed its leaves as "lineari-lanceolata vel sublinearia" to include a wider range of specimens. He made no attempt to describe subordinate formae. ${ }^{2}$ If we return to the concept as held by Bentham, however, we see that it evidently related to broader-leaved material than $\mathrm{f}$. linearis and was intended to include the plants with leaves varying from linearlanceolate to linear-oblanceolate. It is represented by Dodonaea jamaicensis DC. as interpreted in Britton, Fl. Bermuda 225 and illustr. 1918. The forma angustifolia is by far the most widely distributed and abundant forma of var. linearis. At times it approaches var. vulgaris f. Burmanniana and var. arborescens $\mathrm{f}$. spatulata.

Specimens examined for f. 2. angustifolia:

Florida: Charles Henry Baker $547 b$, alt. \pm 15 feet, Volusia County, November 20, 1918 (Gray); A. H. Curtiss 485 p. p., sand ridges between the ocean and Indian River, September (Chi.; Gray; N.Y., 2 sheets); Francis Duckett 236, in tropical pineland, Miami, December 6, 1933 (Calif.; Chi.; N.Y.); A. Fredholm 5603, hammock, Brevard

${ }^{1}$ We may note that $\mathrm{N}$. L. Britton, who had a very extensive acquaintance with Dodonaea in the field for many of the West Indies islands, rejected the Swartz epithet on numerous herbarium sheets (in Herb. N.Y.) as "not D. angustifolia L.f." and then in place of $D$. angustifolia Sw., used the name $D$.jamaicensis DC. Britton used also in his publications (e.g., Fl. Bermuda 225. 1918) the name D. jamaicensis DC. He was undoubtedly actuated by at least two considerations: (1) Because Linnaeus $f$. and Swartz were concerned with plants from opposite sides of the earth, it might be presumed that the plants were taxonomically different; (2) Britton, in later life, was averse to recognizing nomenclaturally any entities lower than species (I rely here not only upon his published works but upon several conversations that I had with him, especially in the summer of 1913 , when he was bringing to a close the revisional work incident to the second edition of Britton and Brown's Illustrated Flora [Illustr. Fl. N. U.S. etc., 3 vols. 1913]). Judging the common angustifolia form as seen in the West Indies to be distinguishable from $D$. viscosa in the latter's narrower sense, he wished to retain it in his botanical works. He therefore construed it as a species. He rejected the Swartz homonym and adopted the later name, $D$. jamaicensis.

2 There was no occasion to do so, since he was concerned at the time with the Brazilian flora and since Brazil apparently was not known to produce other than the typical forma of var. angustifolia. 
County, November 25, 1902 (Gray); A. P.Garber, Miami, April, 1877 (Gray); H.J. Koehler 47, Polk or De Soto County, 1925 (Gray); J.B. McFarlin 8113, Lake Jackson, July 30, 1934 (N.Y.); Harold N. Moldenke 514, shrub about 4.5 feet tall, grassy field near Brickell Hammock, Dade County, January 31, 1930 (N.Y.); J. K. Small \& J.J. Carter 1480, in hammocks, Miami, October 28-November 28, 1903 (N.Y.); Small \& Carter 2588, pinelands between Homestead and Camp Jackson, November 1, 1906 (N.Y.); Small \& Carter 3071, pinelands, island east of Naranja, January 14, 1909 (N.Y.); Small $\&$ Carter 3168, pinelands, Long Key (Everglades), January 18-26, 1909 (N.Y.); Small, Carter, \& G. K. Small, pinelands, Big Pine Key, February 27, 1911 (N.Y.); Small, Carter, \& Small 3283, Brickell Hammock, south of Miami, February, 1911 (N.Y.); J. K. Small \& J. B. De Winkeler 9069, sandhills east of Sebring, May 1, 1919 (N.Y.); J. K. Small \&G. V. Nash 90, Miami, October 27-November 13, 1901 (N.Y.); Small \& Small 4783, pinelands south of Miami River, November 26-December 20, 1913 (N.Y.); S. M. Tracy 7481 p. p., Sanibel Isl., May 15, 1901 (Chi.; Gray; N.Y.).

Revillagigedo Islands: A. W. Anthony 390, Socorro Isl., MarchJune, 1897 (Gray); Anthony 412, Clarion Isl., March-June, 1897 (Chi.; Gray; N.Y.); F. E. Barkelew 188, San Benedicto Isl., May 27July 3, 1903 (Gray; N.Y.); John Thomas Howell 8363 pro parte, Sulphur Bay, Clarion Isl., March 23, 1932 (Chi.; Gray); Herbert L. Mason 1551, top of sea-cliffs, Clarion Isl., April 26, 1925 (Gray); Mason 1621, Grayson's Cove, Socorro Isl., May 4, 1925 (Chi.).

Mexico: Brother Arsène, Cerro de Santa Maria near Puebla, State of Puebla, November 17, 1909 (N.Y.); Arsène 8863, alt. 2,280 meters, San Angel: Pedregal, Distr. Fed., July 3, 1913 (Chi.); Bourgeau 3012, Valley of Mexico, same date (N.Y.); Dr. Coulter 867, Zimapan, State of Hidalgo (Gray); Leon Diquet, barranca du Río Santiago, State of Jalisco, December, 1899 (N.Y.); E. Langlassé 102 , shrub about 3 meters tall, forming a large forest ("forêt") in volcanic sand, alt. 1,000 meters, at foot of Volcán de Yorullo (Mount Jorullo), State of Michoacán, April 13, 1898 (Gray); E. Lyonnet 17, Lomas, Distr. Fed., September, 1927 (Gray; N.Y.); E. Matuda 2015, Santa Rita, Mapastepec, State of Chiapas, January, 1938 (N.Y., 2 sheets); Seemann, Sierra Madre (Gray).

British Honduras: Percy H. Gentle 1775, shrub, edge of pineland, Gracie Rock, Belize District, January 10, 1936 (Chi.); M.E. Peck 34, pine ridge near Manatee Lagoon, June 11, 1905 (Gray); Peck 960, same place, August 7, 1906 (Gray). 
Colombia: E. P. Killip 11269 pro parte, shrub, Cordillera Occidental, Restrepo, Dept. El Valle, September 16, 1922 (N.Y.); Killip \& Albert C. Smith 19765 pro parte, shrub 2-5 feet tall, open hillside, alt. 2,700 meters, between Mutiscua and Pamplona, Dept. Norte de Santander, February 23, 1927 (N.Y.).

Venezuela: Alfredo Jahn 807, alt. 2,700 meters, Merida, January 22, 1922 (N.Y.); Otto Kuntze 1631, alt. $\pm 7,500$ feet, at head of Silla River (N.Y.); E. H. Pittier 211, tree 2-3 meters tall, Heights of Galipan, in savanna, near Caracas, December 19, 1921 (Gray); Padre Cornelio Vogl 104, tree about 7 meters tall, alt. 1,500-2,400 meters, south slope of Cerro Avila, Distr. Fed., August 30, 1939 (Chi.).

Ecuador: Ed. André K.580, Cisne (Chi.; Gray; N.Y.); Erica Heinrichs 22, shrub $9 \mathrm{dm}$. tall, alt. 2,650 meters, everywhere even to 3,000 meters, stony slope on the Río Ambato, November 1, 1932 (N.Y.); Albert S. Hitchcock 21582, much branched shrub 2-4 feet tall, common on dry slopes in hot river valleys, often dominant, alt. 2,700-3,300 meters, between Oña and Cuenca, Prov. Azuay, September 9 and 10, 1923 (Gray); Hitchcock 21720, shrub 3 feet tall, common on dry slope, alt. 2,600 meters, Ambato, Prov. Tungurahua, September 21, 1923 (Gray; N.Y.); C. William Penland \& Robt. H. Summers 77, alt. 1,750 meters, along Pastaza River at Baños, Prov. Tungurahua, March 14, 1939 (Chi., approaching var. vulgaris f. repanda); A. Rimbach 612 p. p., small shrub, dry hills, alt. 2,700 meters, near Riobamba, 1935 (Chi.); Rose, Pachano, \& Rose 23810, vicinity of Cuenca, September 17-24, 1918 (N.Y.); $R$. Spruce 4978, Andes Mountains, 1857-1859 (Gray; N.Y.).

Peru: O. F. Cook \& G. B. Gilbert 737, alt. circ. 3,000 meters, native name, Chamana, Ollantaytambo, May 16, 1915 (Chi.; Gray; N.Y.); Ryozo Kanehira 64, Huánuco, Dept. Huánuco, January 10, 1927 (Chi.); E. P. Killip \& A. C. Smith 21818, shrub 2-4 feet tall, in clefts of bare rock, open hillside, alt. 3,000-3,200 meters, Tarma, Dept. Junín, April 20-22, 1929 (Chi.; N.Y.); J. Francis Macbride 3335 , common shrub on stony western slopes, alt. circ. 9,000 feet, Mito, April 8-18, 1923 (Chi.); H. E. Stork \& O. B. Horton 10095, shrub 1-1.5 meters tall, in shrub-lands, clay soil, alt. 2,800 meters, native name Chamana, leaves mixed with coca if latter is too strong, Sucse River Valley west of Socota, Prov. Cutervo, Dept. Cajamarca, December 9, 1938 (Chi.); C.Vargas 474, environs of Cuzco, in clayey, rocky places, alt. 3,000 meters, Paruro, July, 1937 (Calif.; Chi.); 
Vargas 475, in clayey and rocky places, vicinity of Abancay, Dept. Apurimac, August, 1937 (Chi.).

Brazil: Claussen 27, in 1842 (N.Y.); Alb. Loefgren 10386, Sorocaba, Sao Paulo, October 27, 1887 (N.Y.); L. Riedel \& B. Luschnath 509, February-July, 1832 (N.Y.; Radlkofer, loc. cit. 647, puts this under var. vulgaris f. Burmanniana but it seems slightly closer to $\mathrm{f}$. angustifolia); Weddel 131 p. p., vicinity of Río de Janeiro, 1843 (N.Y., 2 sheets).

Bolivia: Otto Buchtien 93, alt. 3,300 meters, La Paz, April 10, 1901 (Gray); Buchtien 138, shrub 2 meters tall, alt. 2,650 meters, Cotaña, November, 1911 (Chi.; Gray; N.Y.); M. Cárdenas 2124, shrub 1 meter tall, on stony river-sides, alt. 2,000 meters, Mizque, Cochabamba, June, 1940 (Gray); Cárdenas 2845, shrub 2-3 meters tall, in rocky and very dry soil, alt. 1,600 meters, Cordillera of Tucahuasi, Dept. Santa Cruz, native name chakatea, August, 1934 (Chi.); B. A. Krukoff 10707, shrub 30 feet tall, alt. 1,500-1,600 meters, vicinity of Tajma (near Chulumani), Prov. S. Yungas, Dept. La Paz, August 26 and 27, 1939 (Chi.; N.Y.); Otto Kuntze, alt. 3,000 meters, Río Tapacari, March 19, 1892 (N.Y.); G. Mandon 772 , dry places, woods, alt. 2,600 meters, Challapampa, vicinity of Sorata, Prov. Larecaja, December, 1857 to May, 1858 (Gray; N.Y.); H. H. Rusby 101, alt. 5,500 feet, vicinity of Canamina, July 15, 1921 (Gray; N.Y.); José Steinbach 8602 p. p., alt. 2,800 meters, Comarapa, Dept. Santa Cruz, November 1, 1928 (Gray); C. White, alt. 3,500 feet, vicinity of Espia, head of Bopi River, July 22, 1921 (N.Y.); R.S. Williams 190 p. p., bush 8 feet tall, trunk 2 inches in diam., alt. 4,800 feet, Apolo, April 15, 1902 (N.Y.).

Argentina: S. Venturi 8769, shrub about 2 meters tall, alt. 1,000 meters, Candelaria, Dept. Candelaria, Prov. Salta, May 26, 1929 (Gray).

Uruguay: Guil. Herter $701 b$ (5229), 3 meters tall, in dry, stony field, alt. 100-200 meters, native name chilca, Pan de Azúcar, Dept. Maldonado, October, 1907 (N.Y.); W. G. Herter 701c, growing 2-3 meters tall, in dry, stony, clay soil, alt. 200 meters, Sierra Animas, Dept. Maldonado, September, 1929 (N.Y.).

Bermuda: Stewardson Brown 608, hillsides, St. David's Isl., February 10-March 9, 1908 (Chi.; Gray; N.Y.; U.S.); Brown 668, Tucker's Town, May 22-June 2, 1909 (Gray; N.Y.; U.S.); Brown \& N. L. Britton 138, sand-hills, Paget, August 31-September 20, 1905 (Chi.; Gray; N.Y.; U.S.); Brown \& Britton 823, sand-hills, Castle Point, August 27-September 21, 1912 (N.Y.); Brown \& Britton 1022, 
hillside near Bassett's Caves, August 27-September 21, 1912 (N.Y.); Brown \& Britton 1043, cay east of Trunk Isl., Harrington Sound, August 27-September 21, 1912 (N.Y.); Brown \& Britton 1061, hillside, Cooper's Isl., August 27-September 21, 1912 (N.Y.); Brown \& Britton 1068, south end of St. David's Isl., August 27-September 21, 1912 (N.Y.); F. S. Collins 36, hillside near Flatts, May 3, 1912 (Gray); Collins 226, native name dogbush, Walsingham, August 17, 1913 (Chi.; Gray; N.Y.); T. J. Harris 426, April 15, 1906 (Chi.; N.Y.; U.S.); J. W. Harshberger, limestone sinks, Walsingham, June 16, 1905 (N.Y.); C. F. Millspaugh 67, opposite Hamilton, December 29 and 30, 1898 (Chi.); Millspaugh 85, Walsingham, December 31, 1898 (Chi.); Albert Hanford Moore 2861, dry soil, roadside, St. David's Isl., July 8, 1905 (Chi.; Gray).

Cuba: N. L. Britton \& Percy Wilson 5589, coastal thicket, Casilda, Prov. Santa Clara, March 16, 1910 (N.Y.; U.S.); N. L. Britton, E. G. Britton, \& Wilson 15718, bucida thicket, vicinity of Columbia, Isle of Pines, March 19-21, 1916 (Chi.; N.Y.; U.S.); J. G. Jack 8669, cult., 6-8 feet tall, in Harvard Univ. Bot. Garden, from Santa Clara Prov., February 13, 1933 (N.Y.); O. E. Jennings 276B, Isle of Pines, May, 1910 (N.Y.); Jennings 2267, in wet, sandy soil at west base of Mount Colombo, Isle of Pines, May 14, 1910 (Gray; U.S.);Leon \& Edmond 8567, in thickets, Sabana de Motembo, Prov. Santa Clara, January 4, 1919 (U.S.); Antonio Luna 22, Lomas de Banao, Santa Clara, January 9, 1920 (N.Y.); Luna 7668, mountains of St. Spiritus, Loma La Gloria, Gavilanes, January, 1918 (N.Y.); Elizabeth R. Mitchell 5, shrub 5 feet tall, in red soil with much iron, on dry hilltop, alt. 2,000 feet, Nipe Mountains, Prov. Oriente, March 1, 1928 (Gray; U.S.); Leon \& Roca 7982, alt. 900 meters, Loma la Gloria, Banas Mountains, Prov. Santa Clara, July 30, 1918 (U.S.); J. A. Shafer 2981, slender shrub 3-6 feet tall, forming thickets after fire, pine lands, Sierra Nipe, near Woodfred, Prov. Oriente, December 4, 1909 (Chi.; N.Y., 2 sheets; U.S.); Shafer 3590, tree 18 feet tall, trunk diam. 3 inches, open pine woods, alt. 500-650 meters, Sierra Nipe, near Woodfred, December 18, 1909 (Chi.; N.Y.; U.S.); Shafer 11985, slender shrub 6-8 feet tall, on blue serpentine, in thicket, Bahia Honda to El Rosario, Prov. Pinar del Rio, January 29, 1912 (Chi.; N.Y.; U.S.); Shafer 12433, shrub 6 feet tall, dry hillside, Holquin, Prov. Oriente, April 4, 1912 (N.Y.); C. Wright 2172, Palenque, 1860-1864 (Gray); Wright (similarly) 2172, in 1865 (N.Y.; U.S.).

Santo Domingo: W.L. Abbott 1942, alt. 600 to 850 meters or less, Maniel Viejo, Prov. de Barahona, March 7-10, 1922 (U.S., 2 sheets); 
E. L. Ekman H9294, alt. 1,100 meters, Haiti, November 13, 1927 (U.S.); Miguel Fuertes 189, alt. 50 meters, at Palomino Rivulet, near Barahona, Prov. Barahona, 1912 (Chi., where approaching f. linearis; Gray); Jaeger 78, Haiti (N.Y.); E. C. Leonard 4274, alt. about 1,300 meters, vicinity of Furcy, Haiti, May 26-June 15, 1920 (approaching f. spatulata; Gray; N.Y.; U.S.); E. C. Leonard \& Genevieve $M$. Leonard 14995, slender tree 15 feet tall, alt. 630-1,500 meters, Moustique Mountains, vicinity of Bassin Bleu, Haiti, April 21, 1929 (N.Y.; U.S.); George V. Nash 1762, shrub or small tree, 8-12 feet tall, alt. 3,000 feet, mountain slope, La Brande to Mount Balance, Haiti, August 15, 1905 (N.Y.); H. von Tuerckheim 2970, near Constanza on dry slopes, February, 1910 (Chi.; Gray; N.Y.; U.S.); E. J. Valeur 851, tree, open soil, native name Palo de Reina, alt. 3,0004,000 meters, Moncion, Prov. Monte Cristy, April 18, 1933 (N.Y.; approaching f. spatulata); Valeur 910, tree, native name Palo de Reina, Loma Bajita, Dominican Republic, June 9, 1933 (N.Y.).

Jamaica: R. C. Alexander, Siguanea Hills, 1850 (N.Y.); N. L. Britton 1098, Malvern to Stanmore Hill, Santa Cruz Mountains, September 3, 1907 (Chi.; N.Y.; U.S.); E. Campbell 5887, alt. 400 feet, King's House, September 9, 1895 (Chi.; U.S.); J. Arthur Harris \& John V. Lawrence C1598, leeward slopes, Cinchona, Blue Mountains, 1915 (N.Y.; U.S.); William Harris, September 9, 1895 (Chi.); Wm. Harris 8578, Cinchona, May 27, 1903 (Chi.; N.Y.); Wm. Harris 9658, alt. 2,200 feet, Malvern, 1907 (Chi.; N.Y.; U.S.); Wm. Harris 11753, shrub or small tree up to 15 feet tall, alt. 300-900 feet, Lititz Savanna, 1914 (Chi.; Gray; N.Y.; U.S.); John Hart 2025, in 1886 (Chi.; U.S.); Mr. March 240 (N.Y.); William R. Maxon 1197, on shaded banks, alt. 1,500 meters, Cinchona, April 17, 1903 (Chi.; U.S.); Maxon 1342, alt. 1,500 meters, vicinity of Cinchona, March 22, 1920 (Chi.); Maxon 1506, shrub 10 feet tall, near Green River on trail from Cinchona to Blue Mountain Peak, April 22, 1903 (U.S.); Maxon \& Ellsworth Killip 581, on open, shady slopes, alt. 1,475 meters, vicinity of St. Helen's Gap, St. Andrew, March 4, 1920 (Chi.; Gray; U.S.); Maxon \& Killip 1342, alt. 1,500 meters, vicinity of Cinchona, March 22, 1920 (Gray; U.S.); George Nichols 170, wood borders, alt. 5,000 feet, Cinchona, July 27, 1903 (Chi.; Gray; N.Y.; U.S.); C. R. Orcutt 3055, Arntully, September 26, 1927 (U.S.); Orcutt 5118, Arntully (Calif.; U.S.); J. R. Perkins 1238, Blue Mountains, Portland, April 5, 1916 (Gray); Forrest Shreve, on dry slopes, Cinchona, May, 1903 (N.Y.).

Puerto Rico: Oersted 2994, on Mount Candelaria, February, 1847 (Chi.). 
Pretoria: O. B. Miller (Forest Dept. Herb. no.) 4081, on abandoned forest lands, 5 feet tall, important in promoting regeneration, Distr. Flagstaff C. P., April, 1922 (Arn.).

Arabia: Botta, Taifa, 1838 (N.Y.); G. Schweinfurth 743, Mahsabe bei Wolledje, January 19, 1889 (Gray).

Iraq: Yusuf Lazar 558, near Bagdad, March, 1935 (Chi.; Gray).

Persia: J. Bornmüller 655, March 12, 1893 (Arn.).

Afghanistan: East India Company 1021/1 (Gray).

British East India:Bis Ram 436, native name santha, Camp Ana, Salt Range, Punjab, 1928 (Arn.; N.Y.); R. R. Stewart 1076, cult. as hedge, Pathankot, Punjab, February 8, 1917 (Arn.); R. Strachey \& J.E. Winterbottom, alt. 1,500 feet, Simla Hills, Himalaya (Gray); T. Thomson, alt. 1-2,000 feet, northwest Himalaya (Gray); Mrs. Kanoth Yeshoda 78, alt. 3,000 feet, Hosur Taluk, Distr. Salem, south India, October 9, 1931 (N.Y.); Mrs. Yeshoda (similarly) 78, same place, May 24, 1932 (Arn.); Mrs. Yeshoda 78A, same place, January 15, 1932 (N.Y.).

China (including Hainan): Luetta Chen 52A, growing 3.5 feet tall, Kushan Monastery near Foochow, Fukien, October 4, 1935 (Arn.); N. K. Chun \& C.L. Tso 43932, tree 5 meters tall, trunk diam. $10 \mathrm{~cm}$., alt. 2,400 feet, in thickets, Dung Ka, Hainan, September 25, 1932 (N.Y.); H. H. Chung 4677 and 5486 (N.Y.); Chung 4932, shrub at top of hill, Amoy, Nanputo, Fukien, June 5 (Arn.); Chung 7402, Fukien Province (Chi.); Fortune 24, in 1845 (Gray); J. Linsley Gressitt 1765, shrub 1 meter tall, on partly wooded hill, alt. 250 meters, Kakchieh, Swatow, East Kwantung, August 8, 1936 (Arn.); S. K. Lau 2832, fairly common on dry, gentle, sandy slope, in thicket, 3 meters tall, trunk $3 \mathrm{~cm}$. diam., Ka Chik Shan and vicinity, Ch'angkiang Distr., Hainan, December 15, 1933 (Arn.); T. N. Liou 1596, Amoy, Kulangyü, Fukien, September 1, 1930 (N.Y.); F. A. McClure, herb. no. 7933, Hainan, 1921-1922 (Arn.); T. Thomson 1450, grassy hills, Isl. Kulungsu, over against Town of Amoy, August, 1865 (Gray); Tsang Wai Tak 202, behind Hui Ka, Lin Fa Shan and vicinity, Lam Ko Distr., Hainan, July 30, 1927 (Arn.; Calif.; N.Y.).

Formosa: Abbé Urbain Faurie 271, Hokuto (Arn.); K. Odashima 17825, Sirin, Taihoku-syu, July 10, 1935 (Arn.; Chi.; N.Y.); Odashima 17880, same place, May 29, 1934 (Arn.; Chi.; N.Y., 2 sheets); Richard Oldham 83, Tamsuy, 1864 (Chi.; Gray; N.Y., 2 sheets).

Philippine Islands: $M$. Ramos 4912, Pangasinan Province, Isl. Luzon, December, 1907 (N.Y.); J. K. Santos 31739, Benguet Subprovince, Isl. Luzon, April-June, 1918 (Arn.). 
Netherlands East Indies:Forest Serv. 16991, May 26, 1932 (Arn.).

New Caledonia: I. Franc 637, in thickets near the shore, Nouméa, July, 1909 (Arn.; Chi.; Gray, 2 sheets; N.Y.; U.S.); Franc (similarly) 637, December, 1906 (N.Y.); Franc 2382, shrub 2 meters tall, Nouméa, 1929 (Arn.); Franc 2460, shrub in thickets on slopes, Nouméa (Ouen Toro), 1930 (Arn.; Calif.; Chi.; N.Y.; U.S.).

Fiji Islands: Otto Degener 15347, shrub 2.5-3 feet tall, dry grassland, alt. 50-200 meters, Mataimeravula, vicinity of Rewasa, Ra, Viti Levu, May 28, 1941 (Arn.); J. Horne 386, annis 1877-1878 (Gray); B. Seemann 72, in 1860 (Gray); Albert C. Smith 826 p. p., tree 4 meters tall, on exposed cliff-head, native name wosi, alt. 150-350 meters, hills west of Mbutha Bay, Natewa Peninsula, Thakaundrove, Vanua Levu, December 21, 1933 (Calif.; N.Y.); Smith 1425, shrub 2 meters tall, in open places, alt. 100-200 meters, central volcanic section, near Lomaloma, Vanua Mbalavu, March 28, 1934 (N.Y.); United States Explor. Exped. under Capt. Wilkes, 1838-1842 (Gray).

Australia: J.L. Boorman, Gunnedah, New South Wales, August, 1907 (Chi.); Miss O. M. Court, on sand-hills, Yeppoon, Queensland, July, 1925 (Arn.); Sabine Helms 1120, shrub, Magnetic Isl., north Queensland, 1922 (Arn.); E. J. Smith, Mount Edwards, September, 1933 (Arn.).

New Zealand: Banks \& Solander (Capt. Cook's 1st Voyage), 1768-1771 (U.S.); T. F. Cheeseman, Woodhill, North Isl., October, 1882 (U.S.); $M r$. Dupetit-Thonar, Baie des Iles (Gray); T. Kirk, North Isl. (Gray); Kirk 86, Kaipaia, North Isl. (U.S.); Kirk (similarly) 86, Omaha, North Isl. (Gray); D. Petrie 138, Hawkes Bay, North Isl. (Gray); Védel, in 1847 (U.S.).

Dodonaea viscosa var. $\beta$ linearis f. 3. arizonica (A. Nels.) Sherff, Amer. Journ. Bot. 32:214. 1945. Dodonaea arizonica A. Nels. ibid. 21: 576. 1934 .

This forma differs from the two previous formae in having definitely pubescent branchlets to the inflorescence. In the first two formae, the branchlets are glabrous to obscurely or sparsely setulose.

Occasionally a very few of the hairs on the branches of the inflorescence are somewhat closer together in pairs, suggesting an approach to $D$. eriocarpa of the Hawaiian Islands, the Galapagos Islands, and the Island of Java, which in many of its varieties has a more or less stellate pubescence.

Specimens examined for f. 3. arizonica: 
Western Texas: A. Schott, Bravo del Norte (Chi.).

Arizona: Alice Eastwood 15952, near Fish Creek, on Apache Trail, October 22, 1928 (Chi.); Sister Mary Noel Fochtman 217, lower slopes of Baboquivari Mountains, December 2, 1936 (Chi.; N.Y.); F. Raymond Fosberg 7498, shrubs 2 meters tall, rocky slopes, foothills of Baboquivari Mountains, Pima County, April 2, 1932 (Chi.); J. W. Gillespie 5388, alt. 3,300 feet, canyon near Superior, Pinal County, March 19, 1932 (Calif.; N.Y.); Gillespie 8539, alt. 2,800 feet, Apache Gap, on Apache Trail, Pinal County, October 11, 1931 (Calif.; Gray); M. F. Gilman 141, Fresnal, Pima County, April 13, 1928 (N.Y.); Herbert W. Graham, picnic grounds, Sabino Canyon, alt. 3,000 feet, Santa Catalina Mountains, June 25, 1927 (Calif.; N.Y.); David Griffiths 2132, on trip to Castle Rock, November 17, 1900 (N.Y.); Griffiths 2530, Sabino Canyon, March 23, 1901 (N.Y.); J. Arthur Harris C14143, Pima Canyon, Santa Catalina Mountains, April 3, 1914 (N.Y.); Harris C16572, at mouth of Sabino Canyon, Santa Catalina Mountains, August 19, 1916 (N.Y.); M.E. Jones, Mescal Mountains, May 24, 1890 (Calif.; Gray); Jones, alt. 3,000 feet, Sabino Canyon, Catalina Mountains, August 20, 1903 (N.Y.); Jones, Baboquivari Mountains, September 19, 1929 (Gray; N.Y.); J. G. Lemmon, Fort Lowell, 1880 (Gray); Lemmon, San Antonio Creek near Fort Lowell, 1880 (Chi.); F. E. Lloyd, Pima Canyon, vicinity of Tucson, November 11, 1906 (Chi.); Lloyd, Vent Canyon, vicinity of Tucson, April 24, year not certain (Chi.; Gray); Aven Nelson 10307, hillsides along Apache Trail, Phoenix-Globe Highway, May 3, 1925 (N.Y.); Nelson 11276, hillsides between Canyon Lake and Roosevelt Dam, Salt River, March 20, 1930 (type collection, N.Y.); Aven Nelson \& Ruth A. Nelson 1151, foothills of the Baboquivari Mountains, March 13, 1935 (Calif.; Gray; N.Y.); W. F. Parrish, Lowell, May 9, 1884 (Chi.); R. H. Peebles 11653, "wings of fruit usually 3, occasionally 4," alt. 1,950 feet, Ash Creek, Apache Trail, Maricopa County, May 19, 1935 (Chi.); C. G. Pringle, by streams of the Santa Catalina Mountains, flowers June 27, fruit April 18, 1881 (Chi.; Gray); C. L. Shear 4246, Santa Catalina Mountains, April 10, 1906 (N.Y.); Forrest Shreve 5139, tree 12 feet tall, alt. 3,200 feet, Pima Canyon, Santa Catalina Mountains, April 4, 1917 (Calif.; Gray); W. T. Swingle, Allison Dam, Baboquivari Mountains, Pima County, July 10, 1931 (N.Y.); J. W. Toumey, Tucson, January-May, 1894 (Calif.; Gray; N.Y.); Toumey, Tucson, 1895 (N.Y.); M. C. Wiegand \& G. B. Upton 4614, Sabino Canyon, Tucson, April 22, 1922 (Chi.). 
Sonora, Mexico: H. S. Gentry 1389, on oak ridge and pine mesa, 6-7 feet tall, in lower canyon becoming a tree, Sierra Chiribo, Río Mayo, March 7, 1935 (Calif.; Chi.); Edward Palmer 290, waterfall, mountains, Guaymas, October, 1887 (Calif.; Gray; N.Y.); George Thurber, Rayon to Ures, 1852 (Gray); Thurber 909, mountain pass between Magdalena and Cucurpe, October, 1851 (Gray; N.Y.); Stephen S. White 2800, slender shrub 1 meter tall, Tarachique, Cañon de la Escalera, June 23, 1940 (Calif.); Ira L. Wiggins 5913, granitic hills 2 miles south of Sasabe, October 21, 1932 (Calif.); Wiggins 7156, gravelly, red soil, 20 miles southeast of Magdalena, September 12, 1934 (Calif.).

Dodonaea viscosa var. $\gamma$ arborescens (Cunn.) Sherff, Amer. Journ. Bot. 32: 214. 1945 and f. arborescens Sherff loc. cit. Dodonaea arborescens Cunningham ex W. J. Hook. Journ. Bot. 1: 251. 1834 (as a syn. for $D$. Aspleniifolia var. $\beta$ W. J. Hook. loc. cit.). Dodonaea Aspleniifolia var. arborescens (Cunn.) J. D. Hook. ex W. J. Hook. op. cit. 2: 415. 1840.

Bentham (Fl. Austral. 1: 476. 1863), as already stated, treated Dodonaea viscosa as having three varieties, namely vulgaris, angustifolia (our linearis), and spatulata. ${ }^{1}$ The third variety, which we may now notice in detail, had been described years before by Smith (in Rees et al. Cyclop. 12: sub Dodonaea. 1809) as the species Dodonaea spatulata. Bentham wrote: "Usually a more bushy and not so tall a shrub as the preceding varieties, often very viscid. Leaves shorter . . . obovate-oblong, oblong-cuneate, spathulate, oblanceolate or broadly linear-cuneate, usually obtuse or sometimes truncate, the lateral veins usually conspicuous.... Capsules very variable, but generally intermediate between those of the var. vulgaris and angustifolia, but nearer to the former.... This is the commonest, perhaps the only form in Victoria, Tasmania, and S. Australia... and some of the Sandwich Island specimens can be precisely matched in Australia.... D. asplenifolia, Rudge, in Trans. Linn. Soc. xi. 297 , t. $20 \ldots$ is an apparently rare form with linear-cuneate, 3toothed leaves...."

There seems no question that Bentham's judgment as to $D$. Aspleniifolia Rudge (based on a plant from near Port Jackson, at Sydney, New South Wales) was sound. However, Bentham appears to have

I As already noted, Smith's original spelling spatulata was altered by Bentham to spathulata. Since each spelling has good standing in the Latin, I have retained Smith's on grounds of priority. 
overlooked Allan Cunningham's name arborescens, which had been assigned to varietal status in 1840, and, according to present rules, must be taken up in place of spatulata. The type of var. arborescens was Ronald Gunn 377, Tasmania. It had been given the manuscript name Dodonaea arborescens by Cunningham but was reduced by W. J. Hooker to a variety of the Australian D. Aspleniifolia and described as follows: "Var. $\beta$ foliorum apicibus magis dentatosinuatis, ramis angustioribus." I have seen several specimens from eastern Australia and from Tasmania that answer to this leafdescription. Many or most of their leaves are more or less sinuatedentate at the apex and somewhat down the margins. A specimen even from Florida (Small \& Wilson 2035) and apparently one from Ecuador (Hitchcock 21411) are identical. None of the specimens examined appear in any way teratological or monstrous. They may, therefore, be taken as representing a true taxonomic entity, in this case a variety. This variety in its strictest sense, exemplified by its type, Gunn 377 from Tasmania, may be designated further as f. 1. arborescens, foliorum apicibus marginibusque plus minusve sinuato-dentatis. ${ }^{1}$

Specimens examined, f. 1. arborescens only:

Florida: J. K. Small \& P. Wilson 2035, in woods near the beach, St. Augustine, May 22, 1904 (N.Y.; remarkable as being American, but in aspect close to Tasmanian plants of this form).

Ecuador: Albert S. Hitchcock 21411, shrub, on dry hill, alt. 1,8002,600 meters, between La Toma and Loja, Prov. Loja, September 4, 1923 (Gray; N.Y.; scarcely typical but, particularly at Gray, closer to this forma than to f. spatulata).

France: Ch. Naudin, Villa Thuret (where evidently cultivated), March 24, 1887 (Arn.).

Australia: Caly, Parramatta, New South Wales, 1803 (Arn.); S.L.Everist 741, small tree with slender branches, Noondoo, Maranoa District, Queensland, December 14, 1934 (Arn.);Everist 1825, slender shrub up to 8 feet tall in gray clay soil, Lisgool, Mitchell District, Queensland, June 20, 1939 (Arn.); W. D. Francis, Wallumbilla, Western Railway Line, Queensland, September 15 and 16, 1925 (Arn.); C. E. Hubbard 5101, in sandy soil, open eucalyptus forest, alt. circ. 900 feet, near Wandoan, Queensland, November 17 and

1 Through its f. arborescens, $D$. viscosa approaches the usually narrowerleaved $D$. attenuata Cunn. of Australia. In the latter species, one or two lateral lobes or leaflets often occur irregularly along the leaf-blade, suggestive of the pinnately compound-leaved species of Dodonaea. 
18, 1930 (Arn.); Hubbard 5697, among granite boulders and in crevices of rocks in open forest, alt. 3,300 feet, Stanthorpe, Great Dividing Range, Queensland, 1931 (Arn.); C. T. White, Crow's Nest, North Darling Downs, Queensland (Arn.); White, Inglewood, southeastern Queensland, November, 1922 (Arn.); White 9503, shrub 2 meters tall, Roma, Queensland, October 25, 1933 (Arn.); H. B. Williamson, Mount Fero, Victoria, October, 1927 (Chi.).

Tasmania: William Archer (U.S.; topotype and clearly a typical specimen); J. H. Maiden, Risdon Cove ("Robert Brown collected here in 1803"), February, 1906 (Calif.); C. T. White 8326, upright shrub or small tree, 2-3 meters tall, common on dry, stony hillsides, Bellarive, near Hobart, 1932 (Arn.). ${ }^{1}$

Bentham's description of his third variety, spatulata, evidently covers a considerable number of slightly varying races or strains with leaves more or less spatulate, but not or only negligibly dentate or sinuate. Most of these are best represented by the type (Kew) of Dodonaea spatulata Smith from the Hawaiian Islands and may be called more precisely D. viscosa var. arborescens f. 2. spatulata (Smith) Sherff (Amer. Journ. Bot. 32: 214. 1945). ${ }^{2}$ (For certain broaderleaved material, see f. Ehrenbergii below.)

Specimens examined for f. 2. spatulata:

Florida: $M r$. Blodgett, low shrub, Charlotte Harbor (N.Y.); A. H. Curtiss $485 p$. p., on sand ridges between the ocean and Indian River, September (Chi.; N.Y.); A. P. Garber, St. Augustine, July, 1876 (N.Y.); $F$. W. Hunnewell 8755, in sandy woods near beach, St. John County, March 1, 1923 (Gray); J. K. Small 2314, in woods near beach, St. Augustine, December 2, 1904 (N.Y.); Small \& J. B. De Winkeler 9037, on sandhills, Avon Park to Sebring, May 1, 1919 (N.Y.); S. M. Tracy 7481 p. p., Sanibel Isl., May 15, 1901 (Calif.; Chi.).

Mexico: C. Conzatti 1498, alt. 2,200 meters, Alturas de Matatlán, State of Oaxaca, June 19-23, 1906 (N.Y.); Edward Palmer 495, alt. about 320 meters, vicinity of Victoria, State of Tamaulipas, May 1-June 13, 1907 (Calif.; Gray); C. A. Purpus 121, alt. 6,0007,000 feet, San Pablo, Baja California, January-March, 1898 (N.Y.);

1 The Francis and Hubbard and White specimens belong with f. arborescens but display an approach toward f. spatulata.

${ }^{2}$ Dodonaea viscosa f. arborea Hert. Rev. S. Amer. Bot. 3: 168. 1936. Nomen. D. arborea Hert. op. cit. 5: 35. 1937.-Herter's type basis was his no. 96921, from Cerro Animas, Dept. Maldonado, Uruguay, an excellent isotype of which I have before me (Chi.). It can be matched by various specimens of f. spatulata from Australia, Hawaiian Islands, and elsewhere. 
F. Lyle Wynd \& C. H. Mueller 89, along dry creek bed, between Hipolito and Sacramento, State of Coahuila, June 15, 1936 (N.Y.).

Colombia:F.W. Pennell 2352, shrub, on grassy hill 4 miles southwest of Bogota, alt. 2,700-2,800 meters, October 4-8, 1917 (Chi.; Gray; N.Y.).

Peru: C. Vargas 9781, shrub, 1-3 meters tall, alt. 2,300-2,800 meters, on clayey or rocky slopes, common in xerophytic canyons of the Apurimac system, Hacienda Jucre, Prov. Grau, Dept. Apurimac, native name chaman or chamana, January 18, 1939 (Calif.; Chi.); Llewelyn Williams 7564, shrub, alt. 2,700 meters, on sierras, Chachapoyas, Dept. Amazonas, January, 1930 (Chi.).

Bolivia: José Steinbach 6017, shrub, 103 meters tall, native name chaka-tía, alt. 2,000-3,600 meters, Dept. Cochabamba (Chi.).

Uruguay: W. G. Herter (herb. no.) 96921, growing 5 meters tall, alt. 50 meters, in dryish, open, stony places, Cerro Animas, Dept. Maldonado, April 10, 1936 (Chi.; sub nom. D. viscosa f. arborea Hert.); (ex herb.) C. Diego Legrand 792, Cerro Animas, Maldonado, native name chilca de sierra, June 16, 1936 (Chi.).

Island of Socotra: Commun. Bayley Balfour 659, FebruaryMarch, 1880 (Gray).

Kenya Colony:Edgar A. Mearns 387 p. p., alt. circ. 2,000 meters, between Oljoro-o-Nyon and Narok rivers, June 7 and 8, 1909 (Chi.; Gray).

British East India: Eileen W. Erlanson 5178, undershrub, dry hillside, Trivandrum, Travancore, January 8, 1934 (N.Y.); Schlagintweit, alt. 1,400-2,500 feet, Musakél, Prov. Punjab, February 17March 5, 1857 (Gray); R. R. Stewart $16570 B$, alt. 2,000 feet, Nurpur, Rawalpindi District, Punjab, February-April, 1938 (Arn.).

Indo-China: $J$. \& M. S. Clemens 3210 p. p., common dune shrub, Tourane (Turan) and vicinity, Annam (Anam), May 23-26, 1927 (Calif.; N.Y.); C. B. Robinson 1056, Nha-trang and vicinity, Annam, March 11-26, 1911 (N.Y.).

Philippine Islands: R. C. McGregor 43622, Burgos, Prov. Ilocos Norte, Isl. Luzon, November, 1923 (Arn.; Calif.); Ramos 27157, Burgos, February and March, 1917 (Arn.).

Fiji Islands: Albert $C$. Smith 86, slender tree 4 meters tall, native name usi, among reeds, alt. 200-400 meters, on hills, above Namalata and Ngaloa bays, Kandavu, October 13-18, 1933 I(Calif.; N.Y.; U.S.).

New Caledonia: Vieillard 246, Wagap, Gatopa, 1861-1867 (N.Y.). 
Cook Islands: Harold E. Parks \& Susan Thew Parks 22332, Isl. Rarotonga, May-July, 1929 (Calif.; Chi.; Gray; N.Y.); Gerrit Wilder, same island, 1929 (N.Y.).

Hawaiian Islands in general or from Oahu (for Lanai, etc. see below): $M r$. W. Hancock (Kew no.) 51, in 1898 (Kew); A. Menzies, topmost shrubs on the Sandwich Islands, alt. 6,000 feet (Kew, type material); W. A. Bryan, Diamond Head, Oahu, December 6, 1903 (Bish.); Degener, Topping, Martinez, \& Salucop 11195, below forest, on ridge directly north of Kaala summit, Oahu, March 26, 1937 (Arn.; Berl.; Calif.; Chi.; Corn.; Del.; Gray; Par.); F. R. Fosberg 13184, shrub 1.5 meters tall, alt. 20 meters, on dry, rocky bluff, Keaau, July 24, 1936 (Chi., etc.); Fosberg 13185, shrub 2 meters tall, same place and date (Chi., etc.); $F$. R. Fosberg \& Katherine Duker 9049 , small tree 2.5 meters tall, alt. 480 meters, in dry forest, head of Makua Valley, Makua, November 25, 1932 (Chi.); Mann \& Brigham 582 (Bish.); J. M. Oliveira \& V. O. Fosberg 97, on dry, bushy slope, east slope of head of Kalama Valley, Maunalua, Oahu, March 7, 1937 (Chi., etc.); O. Selling, cult., Kamehameha School garden, Honolulu, Oahu, June 30, 1938 (Goth.).

Hawaiian Islands: Lanai: George C. Munro 68, native name aalii, Kaluanui, flowering April 16, 1914 and seeding September 26, 1913 (Bish.); Munro 121, Kaluanui, bend beyond Waipaa (i.e., Waiapaa), September 26, 1913 (Bish.); Emilio Ordoñez (Degener distrib. no.) 12846, Puu Alii, July 14, 1940 (Arn.; Berl.; Calif.; Chi.; Corn.; Gray; Minn.; Mo.; Phila.).

Hawaiian Islands: Maui: Cranwell, Selling, \& Skottsberg 2802, in brushwood on crater floor, Haleakala, August 4, 1938 (Goth.); C. N. Forbes 2009-M, on south slope of Haleakala, March 18, 1920 (Bish.; Chi., etc.).

Hawaiian Islands: Hawaii: Cranwell, Selling, \& Skottsberg 3259, vicinity of Kilauea, September 12, 1938 (Goth.); Otto Degener 11150, in arid regions, in volcanic ash near crater, Kilauea, December 10, 1922 (Arn.; Chi.; N.Y.); Degener 11151, in hot, sunny situation near ocean, near Hawaiian rock-figures, Kamoamoa, August 23, 1922 (Arn.; Berl.; Chi.); Degener 11152, in lava desert, Kilauea, December 18, 1922 (Chi.); Degener 11158, in rocky pasture, Punaluu, July 25, 1926 (Chi.); Degener 11170, in dry region, Kipuka Puaulu, Kilauea, July 8, 1929 (Arn.; Berl.; Chi.; Del.; N.Y.); Degener 11172, near Volcano House, Kilauea, July 20, 1929 (Chi.); Alice Eastwood, bird forest near volcano, August 1-16, 1924 (N.Y.); Abbé Urbain Faurie 278, alt. 2,000 meters, Mauna Kea, July, 1909 
(Arn.; Del.; Par.); C. N. Forbes, Kilauea (Bish.); Forbes 305- H, on slopes of Mauna Loa, near Puu o Uo, Kona, July 9, 1911 (Bish.; Calif.; Mo.); Forbes 308- H, on slopes of Mauna Loa, below Puu o Uo, July 14, 1911 (Bish.); Forbes 966- H, June 27, 1915 (Bish., etc.); Forbes 976- H, kipukas in Lava Flow of 1823, at level of Keawewai, June 28, 1915 (Bish.); Forbes 1032- H, above Puu a Ulu, July 1, 1915 (Bish.); Forbes with Brigham \& C. L. Thompson, Volcano Kilauea, September, 1908 (Bish.; Calif.; Mo.; N.Y.); F. R. Fosberg 10146, bush 1 meter tall, alt. 950 meters, on pahoehoe lava, Mauna Iki, Kau Desert, August 31, 1933 (Chi., etc.); Fosberg 10148, bush 1.5 meters tall, alt. 900 meters, on old lava, Volcano Road above Mauna Iki, August 31, 1933 (Chi., etc.); V. O. Fosberg 51, bush 2-3 meters tall, dry lava flow, between 1887 and 1868 flows, August 10, 1936 (Chi.); Galathea Expedition 3390, years 1845-1847 (Bish.); Constance Hartt \& M. Neal 877, alt. 6,500 feet, Humuula, August 19, 1935 (Bish.); Hartt \& Neal 878, alt. 6,500 feet, same place and date (Bish.); William Hillebrand, Isl. Hawaii (Kew); Hillebrand, alt. 4,000 feet, July, 1865 (Chi.); A. S. Hitchcock 14638, alt. 5,000 feet, Mauna Loa, September 13, 1916 (U.S.); Mrs. G. Earle Kelly 261, Kilauea, July, 1916 (Arn.); Mann \& Brigham, Kilauea (Bish.); Mann \& Brigham 308, central plateau of Hawaii (Gray; Mo.); Mann \& Brigham 410, Kilauea (Chi.; N.Y.); Marie C. Neal, Kilauea Summer Camp, Kilauea, July 28, 1927 (Bish.); Neal, same place, August 16, 1929 (Bish.; Chi.); Neal, Hartt, \& John Martin, alt. 8,250 feet, summit of Mount Hualalai, June 19, 1934 (Bish.; N.Y.); Jules Remy 568, years 1851-1855 (Par.); Joseph F. Rock 3764, summit of Mount Hualalai, June 9, 1909 (Gray); Rock 3766, same place and date (Gray); Rock 3767, same place and date (Gray); Rock 3852, alt. 8,200 feet, same place and date (Bish.; Gray; Par.; U.S.); W. A. \& C. B. Setchell, June 23, 1924 (Calif.); Carl Skottsberg 491, alt. 1,200 meters, crater of Kilauea, December 9, 1922 (Bish.; Goth.); Skottsberg 497, same place, September 12, 1922 (Goth.); Skottsberg 522, below Rest-house, slope of Mauna Loa, September 15, 1922 (Bish.; Goth.); Skottsberg 1121, between Kilauea and Kapapala, September 18, 1922 (Bish.; Goth.); United States Explor. Exped., Isl. Hawaii (Gray; U.S.); U.S. Explor. Exped., at 8,000 feet station, Mauna Loa, 1838-1842 (N.Y., 2 sheets); R. L. Usinger 2, aa lava flat, Humuula, August 3, 1935 (Bish.).

Australia: E. H. Wilson 488, cult., Zoological Gardens, Perth, Western Australia, November, 1920 (Arn.); C. T. White 5502, shrub 8 feet tall, abundant on hillsides, Morialta near Adelaide, 
South Australia, November 19, 1927 (Arn.); J. L. Boorman, Hargreaves, New South Wales, January, 1913 (Chi.).

Tasmania: Caly, December, 1805 (Arn.).

New Zealand: T. Kirk, South Isl. (Chi.).

Dodonaea viscosa var. $\gamma$ arborescens f. 3. Ehrenbergii (Schlecht.) Sherff, Amer. Journ. Bot. 32: 214. 1945. Dodonaea Ehrenbergii Schlecht. Linnaea 17: 639 (sphalm 739). 1843; ibid. 18: 36 (sphalm 52). 1844. Dodonaea viscosa var. obovata Hitchc. Report. Missouri Bot. Gard. 4: 73. 1893. Dodonaea microcarya Small, Torreya 25: 38. 1925.

Because of the extreme polymorphism present in $D$. viscosa, some of its almost innumerable forms frequently look mutually more unlike than many entities that commonly pass as distinct species. Mainly for this reason most of them have been segregated under special names. The name Dodonaea Ehrenbergii was applied by Schlechtendal to a tree or shrub, specimens of which had been collected by C. Ehrenberg on the plains of Santo Domingo. A good specimen of Ehrenberg's original material is in the Herbarium of the New York Botanical Garden. It is matched in varying degrees by an extensive assortment of plants from the West Indies and by some from Florida.

Radlkofer, at various times during his long-continued studies on Dodonaea, examined various collections from the West Indies. In his extensive treatment of $D$. viscosa (in Martius, Fl. Brasil. $13^{\text {III }}$ : 644. 1900), he reduced $D$. Ehrenbergii to $D$. viscosa var. spatulata (which, as shown above, is reducible to a forma of var. arborescens). Numerous herbarium specimens more or less typical for D. Ehrenbergii were labeled by him $D$. viscosa var. spatulata. Thus, for example, as late as June, 1913, he determined a specimen, one quite typical for $D$. Ehrenbergii, as $D$. viscosa var. spatulata. This had been collected by Britton, Britton, \& Cowell, no. 12475, on coastal cliff, Punta Piedra, Nipe Bay, Prov. of Oriente, Cuba, March 7, 1912 (in Herb. N.Y.).

In 1893, Hitchcock (loc. cit.) had described somewhat broadleaved specimens from Cat Island and Inagua (both in the Bahama Islands), giving them the new name $D$. viscosa var. obovata. It may well be doubted, however, that Hitchcock would have erected a new variety for his plants could he have had access to Radlkofer's exhaustive and critical survey, as then unpublished, of Dodonaea viscosa and various of its forms. In recent years, a wealth of speci- 
mens from the general region of the West Indies has been brought into herbaria, doubtless totaling many more than Radlkofer could have had for examination. Generally speaking, these may be said to vary from the usual material of $\mathrm{f}$. spatulata to somewhat the same extent as the formae Burmanniana and Schiedeana do from the typical forma (i.e., f. repanda) of var. vulgaris. Some of the specimens have extremely small fruits $( \pm 5 \mathrm{~mm}$. wide over-all when flattened out). Among these are the ones described by Small (loc. cit.) as Dodonaea microcarya. A great variation occurs, however, in size of fruits, many specimens having medium-sized to larger ones (7-15 or more $\mathrm{mm}$. wide over-all, when flattened out). The leaves are usually shorter and proportionately wider than in var. arborescens proper (i.e., its f. arborescens) and its f. spatulata, more inclined to be broadly rounded or truncate to emarginate at apex, and usually more of a grayish-green (judging from dry material).

It must be noted in all fairness to Radlkofer, that while he had made a substantially cosmopolitan survey of Dodonaea viscosa in literature and plant materials, he was concerned, in the work above cited, almost exclusively with the Brazilian flora. Had he included the West Indies and Florida as within the scope of his treatment, he undoubtedly would have enlarged upon his mere notation of D. viscosa var. spatulata, already cited above (see p. 271) and equivalent essentially to var. arborescens of this paper, and listed for it several formae. At all events, the Dodonaea Ehrenbergii of Schlechtendal, to extend Radlkofer's treatment today at all consistently, would seem best to rank as a forma under var. arborescens. ${ }^{1}$

Specimens examined for f. 3. Ehrenbergii:

Florida: Blodgett, southern Florida (N.Y.); John K. Small 4085, pine lands between Miami and Cocoanut Grove, November 3-

1 It cannot be emphasized too strongly that in certain localities the f. Ehrenbergii may easily appear widely and specifically different from f. arborescens. Future authors of floristic works restricted to such localities will perhaps, therefore, be tempted so to treat it. Then, too, there will doubtless always be some botanists who strive for uniformity in assignment of classificatory status to plant entities regardless of the stability or constancy of these entities, or, more particularly, regardless of their tendency in many parts of their geographic range to form countless intergradations. To these I would merely repeat Asa Gray's observation, "Vain is the attempt to draw absolute limits where Nature luxuriates in gradations." (Proc. Amer. Acad. 5: 126. 1861.)

Finally, we should keep in mind the fact that some few botanists, such as the late N. L. Britton and the late C. F. Millspaugh in the latter part of their lives, abandoned varieties as such, reducing them outright to synonymy with their respective species proper, or reducing them to anonymous "races," or setting them off as individual species. Obviously, in following the nomenclatural pathway marked out for the study of Dodonaea viscosa by Radlkofer, I have made no attempt to conform to the irreconcilable views of such workers. 
December 7, 1912 (N.Y.); Small 9883, hammock, northern end of Big Pine Key, May 9, 1921 (N.Y., sub nom. Dodonaea microcarya Sm.); Small, Alfred Cuthbert, \& Paul Matthaus 9105, hammock, northern part of Big Pine Key, May 8, 1919 (N.Y., 2 sheets, type coll. of D. microcarya Small).

Bahama Islands: L. J. K. Brace 1847, Cherokee Sound, Abaco, December 25, 1904 (Chi.; N.Y.; U.S.); Brace 3942, Port Nelson, Rum Cay, December 4, 1905 (Chi.; N.Y.; U.S.); Brace 4159, Cove Road to South Side, Long Cay, December 7-17, 1905 (Chi.; Gray; N.Y.; U.S.); Brace 4255, Spring Point, Acklin's Isl., December 21, 1905 to January 6, 1906 (Chi.; N.Y.); Brace 4679, Landrail Point, Crooked Isl., January 9-23, 1906 (Chi.; N.Y.; U.S.); Brace 5327, Rose Cay, Northern Bight, Andros, August 18 to September 10, 1906 (Chi.; N.Y.); N. L. Britton \& C.F. Millspaugh 5422, edge of coppice, Glass Window to Gregory Town, Eleuthera, February 18, 1907 (Chi.; N.Y.); Britton \& Millspaugh 5685, coastal whitelands, Little San Salvador, February 25 and 26, 1907 (Chi.; N.Y.); Britton \& Millspaugh 5989, scrub in white land, edge of a salina, Conception Isl., March 9 and 10, 1907 (Chi.; N.Y.);W.C. Coker 444, Port Nelson, Rum Cay, July 10, 1903 (N.Y.); Coker 567, shrub, Abaco, July 20, 1903 (N.Y.); Albert S. Hitchcock, Crooked Isl., November, 1890 (Chi., plus a fragment ex typo in herb. Mo.); Hitchcock, Isl. Inagua, December 3, 1890 (Chi., fragm. ex herb. Mo.); C. F. Millspaugh \& C. M. Millspaugh 9043, in a sisal field, Waterloo and vicinity, Grand Turk Isl., February 20-March 24, 1911 (Chi.; N.Y.); Millspaugh \& Millspaugh 9311, on rocky plain, Ambergris Cay, the Caicos Group, March 12, 1911 (Chi.; N.Y.); George V. Nash \& Norman Taylor 955, Salt Pond Hill, Inagua, October 12, 1904 (Chi.; N.Y.); Nash \& Taylor 1032, Tenados, Inagua, October 14, 1904 (Chi.; N.Y.); Nash \& Taylor 1035, same place and date (Chi.; N.Y.); Nash \& Taylor 1107, Blakeville, Inagua, October 18, 1904 (Chi.; N.Y.); Nash \& Taylor 1421, shrub 4-5 feet tall, white-land, near Lantern Head Creek, Inagua, November 3, 1904 (N.Y.); Nash \& Taylor 3808, shrub, Grand Turk Isl., August 27-September 1, 1905 (N.Y.); J. T. Rothrock 279, Crooked Isl., November 24, 1890 (Chi.; N.Y.); Rothrock 282, growing 8 feet tall, Crooked Isl., winter of 18901891 (Chi.); Percy Wilson 7405, Atwood Cay, December 3 and 4, 1907 (Chi.; N.Y.); Wilson 7500, Abraham Bay and vicinity, Mariguana, December 6-8, 1907 (Chi.; N.Y.); Wilson 7602, South Caicos, Caicos Islands, December 14-16, 1907 (Chi.; N.Y.); Wilson 7700, tree 18 feet tall, Kew and vicinity, North Caicos, December 18, 
1907 (Chi.; N.Y.); Wilson 7875, Hog Cay, Great Ragged Isl., December 26, 1907 (Chi.; N.Y.).

Cuba: Britton, Britton, \& Cowell 12475, shrub 2 meters tall, on coastal cliff, Punta Piedra, Nipe Bay, Prov. Oriente, March 7, 1912 (N.Y.; U.S.); J. A. Shafer 2745, shrub or tree, Cayo Paredon Grande, Camaguey, October 25, 1909 (Chi.; Gray; N.Y.; U.S., 2 sheets); Shafer 2775, eastern part of Cayo Cruz, Camaguey, October 27, 1909 (Chi.; Gray; N.Y.; U.S.).

Haiti, etc.: Harold E. Box 1265, sandy or rocky seashores and dry, exposed, limestone hills, Corbizon Point, Antigua, Brit. W. Indies, November 13, 1937 (U.S.); N. L. Britton \& W. C. Fishlock 968, sandy plain, west end, Anagada, Brit. Virg. Isls., February 19 and 20, 1913 (Chi.; N.Y.; U.S.); Père Duss 2904, growing 2-4 meters tall, Guadeloupe Isl., 1893 (N.Y.); C. Ehrenberg, Isl. Santo Domingo (N.Y.; author's original material); E. L. Ekman H.4942, alt. about 600 meters, Haiti, September 29, 1925 (U.S.); W. C. Fishlock 47, thickets near the shore, Anagada, October, 1918 (Gray; U.S.); E. C. Leonard 4203, vicinity of Fond Parisien, Etang Saumatre, Haiti, May 5-13, 1920 (Chi.; N.Y.; U.S.); Leonard 8879, alt. 325-900 meters, vicinity of Ennery, Dept. l'Artibonite, Haiti, January 14, 1926 (Gray; N.Y.; U.S.); E.C.\& Genevieve M. Leonard 13945, tree 20 feet tall, beach east of harbor, vicinity of Basse Terre, Torue Isl., Haiti, March 22, 1929 (U.S.); Leonard \& Leonard 13946, tree 20 feet tall, same place and date (Gray; N.Y.; U.S.); H. Stehlé 207, alt. 125 meters, plateau, Desirade Isl., W. Indies, November 9, 1935 (N.Y.); F. L. Stevens 6152 and 6289, Mona Isl., December 20 and 21, 1913 (N.Y.).

Dodonaea viscosa var. $\gamma$ arborescens $f .4$. hispidula f. nov.Ramuli foliaque etiam fructus (praecipue alarum margines) plus minusve patenti-hispiduli. Folia sublate spathulata, apice orbiculato vel subtruncato abrupte mucronulata, plerumque $2.5-4.5 \mathrm{~cm}$. longa et $1-1.5 \mathrm{~cm}$. lata.

Branchlets and leaves and even the fruits (especially the edges of the wings) more or less spreading-hispidulous. Leaves subwidely spatulate, abruptly mucronulate at the orbiculate or subtruncate apex, commonly $2.5-4.5 \mathrm{~cm}$. long and $1-1.5 \mathrm{~cm}$. wide.

Specimens examined: T. S. Brandegee 110, Sierra de la Laguna, southernmost Baja California, January 26, 1890 (type, Calif.); C. A. Purpus 219, San José del Cabo, southernmost Baja California (Calif.). 
Here, as in var. linearis f. arizonica and var. vulgaris f. eriocarpoidea, $D$. viscosa shows an approach to $D$. eriocarpa, a species which in its pubescent varieties displays, however, a certain amount of stellate pubescence in the ultimate parts of the inflorescence. The type locality of $\mathrm{f}$. hispidula is famous for endemic forms.

Dodonaea viscosa var. $\delta$ Stokesiana F. Brown, Bishop Mus. Bull. 130: 164. 1935.

The var. Stokesiana was described by Dr. Forest Brown from a number of specimens collected in the Austral Islands and on the Island of Rapa, representing an areal extent limited roughly by about $20^{\circ}$ and $30^{\circ} \mathrm{S}$. Lat. and by about $145^{\circ}$ and $155^{\circ} \mathrm{W}$. Long. Recently I have examined a specimen of one of the collections cited by Brown (Mrs. A. M. Stokes 191, in herb. N.Y.) and have been able to match it closely with several additional specimens not cited by Brown. These are cited below. It will be observed that they extend the known geographic range for var. Stokesiana to about $169^{\circ} \mathrm{E}$. Long. (Erromango Isl.) and to somewhat less than $17^{\circ} \mathrm{S}$. Lat. (Raiatea Isl.).

It is difficult to separate this variety from $D$. viscosa and all its other varieties and forms by any one character, nor indeed did Brown offer a key by which to differentiate var. Stokesiana. In a general way, however, the variety tends to differ in its narrower sepals, its sessile or subsessile leaves, its mostly longer and more slender styles, and its smaller and commonly somewhat hispidulous fruits. Brown's description has seemed too scanty. I have therefore drawn up an amplified description from the specimens at hand:

Dodonaea viscosa var. Stokesiana F. Brown descript. amplific.Folia cuneate oblanceolata, inferne sensim ad basim sessilem vel subsessilem angustata, apice plus minusve rotundata et abrupte apiculata, plerumque 7-9 (rarius \pm 15 ) $\mathrm{cm}$. longa et 1.5-3 (rarius \pm 4 ) $\mathrm{cm}$. lata. Flores minores, 4 vel 5 sepalis linearibus (interdum anguste) vel lanceolatis sparsim hispidulis vix nervatis tantum 1-1.5 mm. longis. Antherae 1.5-2 mm. longae. Stylus debilis, plerumque 5-8 mm. longus, 2- vel 3-partitus, demum saepius persistens. Capsula 2- vel 3-partita -alataque, circ. 6-8 mm. lata, alis angustis ( $\pm 1 \mathrm{~mm}$. latis) exclusis, extus minutissime irregulariterque hispidula.

Leaves cuneately oblanceolate, gradually narrowed below to a sessile or subsessile base, at tip more or less rounded and abruptly apiculate, commonly 7-9 (more rarely \pm 15 ) $\mathrm{cm}$. long and 1.5-3 (more rarely \pm 4 ) $\mathrm{cm}$. wide. Flowers smaller; sepals 4 or 5 , linear 
(at times narrowly so) or lanceolate, sparsely hispidulous, scarcely nerved, only 1-1.5 mm. long. Anthers 1.5-2 mm. long. Style delicate, commonly 5-8 mm. long, 2- or 3-parted, in age more often persistent. Capsule 2- or 3-parted and -winged, about 6-8 $\mathrm{mm}$. wide, the narrow wings $( \pm 1 \mathrm{~mm}$. wide) excluded, at surface irregularly and very minutely hispidulous.

Specimens examined: Degener \& Ordoñez 14205, native name katasai, shrub 1-2 meters tall, on bare forehill, alt. 0-450 meters, Maravu, near Salt Lake, Thakaundrove, Vanua Levu, Fiji Isls., January 17-23, 1941 (Arn.); S. F. Kajewski 296, native name Neyin-temer, common in poor, red soil, bracken country, tree about 6 meters tall, alt. 300 meters, Dillon (Dillion) Bay, Eromanga (Erromango) Isl., New Hebrides, May 24, 1928 (Arn.; N.Y.; U.S.; a form with elongate, thinner, petiolate leaves approaching those of var. linearis f. angustifolia); Archibald Menzies, Isl. Tahiti (Kew); T. Powell 101, Isl. Raiatea, June 29, 1874 (Chi.); W. A. Setchell \& H.E. Parks 547, shrub up to 10 feet tall, dioecious, fruit light Venetian red, common on dry hillside, Mount Tahara, Isl. Tahiti, July 11, 1922 (Calif., 2 sheets; Gray; U.S.); United States South Pacific Exploring Expedition under Captain Wilkes, Isl. Tahiti, 1838-1842 (N.Y., 2 sheets; U.S.); ${ }^{1}$ U. S. S. Pacif. Explor. Exped., Fiji Isls., 1838-1842 (N.Y.).

\section{Conspectus of Varieties and Formae of Dodonaea viscosa Treated IN THIS ARTICLE ${ }^{2}$}

Var. a. vulgaris Benth., p. 270.

f. 1. repanda (Schum. \& Thonn.) Radlk. p. 271. Leaves when typical very large (up to $\pm 13 \mathrm{~cm}$. long and to $\pm 4 \mathrm{~cm}$. wide), mostly oblong to subobovate, more often obtuse at apex. Commonly (like the next two formae) glabrous or glabrate.-Florida, Mexico, Central America southward to Bolivia and Brazil, West Indies, tropical East Africa, China, Malay Archipelago, Australia, Polynesia, etc.

f. 2. Schiedeana (Schlecht.) Radlk. p. 271. Leaves very long (up to $\pm 16 \mathrm{~cm}$. long and to only $\pm 2 \mathrm{~cm}$. wide), elongately lanceolate, gradually narrowed to both ends. Comparatively infrequent.-Mexico, Guatemala, British Honduras, Peru, Bolivia, Brazil, West Indies (Isle of Pines), British East India, and Isls. Timor and Papua.

1 This Tahiti material is that referred to by Asa Gray (Bot. U. S. Explor. Exped. 260. 1854) as being a form of $D$. viscosa with "some of the capsules surmounted by a long exserted style, of 3 or 4 lines in length! . . . while other fruits of the same panicle have the usual short style, not exserted beyond the sinus of the wing."

${ }^{2}$ Besides the four varieties presented here, two more are known, both of southeastern Polynesia and of highly localized distribution: Var. $\epsilon$ minor Sherff (Amer. Journ. Bot. 32: 212. 1945), known only from the Island of Rapa, and var. $\zeta$ marquesensis F. Brown (Bish. Mus. Bull. 130:163. 1935) from the Marquesas Islands. 
f. 3. Burmanniana (Schum. \& Thonn.) Radlk. p. 271. Leaves of medium size (7-11 cm. long and $1.5-2 \mathrm{~cm}$. wide), from oblong to narrowly lanceolate or cuneate or oblanceolate, terminally acute or somewhat obtuse.Widespread in Mexico, Central America, throughout most of South America, Abyssinia to South Rhodesia, southeastern Asia, Malay Archipelago, Australia, Fiji Isls., etc. Apparently absent (as are the other formae of $D$. viscosa except f. spatulata) from Hawaiian Isls. (where it is often simulated by D. eriocarpa var. Degeneri f. decipiens Sherff).

f. 4. eriocarpoidea Sherff, p. 284. Leaves often resembling in shape and size those of $\mathrm{f}$. Burmanniana, f. angustifolia, or even $\mathrm{f}$. spatulata. Inflorescences and ultimate branchlets hispidulous.-Known only from Mexico.

Var. $\beta$. linearis (Harv. \& Sond.) Sherff.

f. 1. linearis Sherff, p. 285 . Leaves linear, now short $( \pm 5 \mathrm{~cm}$.) now long $( \pm 7-11 \mathrm{~cm}$.); branches of inflorescences (as also in f. 2. angustifolia) glabrous to sparsely setulose.-Mexico, Ecuador, Cuba, Haiti, South Africa, Réunion Isl., Formosa, and Australia.

f. 2. angustifolia (Benth.) Sherff, p. 287. Leaves linear-lanceolate to linearoblanceolate, mostly of moderate size.-Florida, Mexico, British Honduras, many parts of South America, southern Asia, Australia, New Zealand, Philippine Isls., etc.

f. 3. arizonica (A. Nels.) Sherff, p. 295. Leaves linear; branches of inflorescences hispidulous.-Arizona and Mexico (State of Sonora; apparently replaced elsewhere in Mexico by var. vulgaris f. eriocarpoidea).

Var. $\gamma$. arborescens (Cunn.) Sherff.

f. 1. arborescens Sherff, p. 297. Tips and lateral margins of leaves more or less sinuate-dentate. This and the next two forms mostly glabrous or glabrate on foliage and fruits.-Rare in Florida and Ecuador; apparently frequent in Australia and Tasmania.

f. 2. spatulata (Smith) Sherff, p. 299. Leaves mostly spatulate, entire or but slightly sinuate-dentate, and of small size (more often 3-6 cm. long and $0.7-1.5 \mathrm{~cm}$. wide). - Of widespread distribution: Florida, Mexico, Colombia to Uruguay, tropical East Africa, southeastern Asia, Polynesia (abundant in Hawaiian Isls.), Australia, Tasmania, and New Zealand.

f. 3. Ehrenbergii (Schlecht.) Sherff, p. 303. Leaves usually shorter and proportionately wider, more inclined to be broadly rounded or truncate to emarginate at a pex, and usually (at least when dry) more of a grayishgreen color. Fruits often very small.-Florida and West Indies.

f. 4. hispidula Sherf, p. 306. Branches, leaves, and fruits more or less spreading-hispidulous. Leaves small, subwidely spatulate.-Southernmost Baja California.

Var.. Stokesiana F. Brown, p. 307.-Austral Isls., Erromango Isl. (New Hebrides), Fiji Isls., and Isls. Raiatea and Tahiti (Society Islands). 


\section{INDEX OF COLLECTORS CITED}

Collectors' names and page numbers in italic type ${ }^{1}$

Abbott, Ruth Q., no. 179, 273 no. 220,273

Abbott, W. L., no. 1942, 292 no. 2564,275

Adduru, no. 8 pro parte, 276 and 283 Alexander, $R$. C., Port Royal Mts., Apr., 1850, 275

Siguanea Hills, 1850, 293

André, Edouard, no. K.580, 290

Andrieux, G., no. 488, 284

Anglade, Father, alt. 1,000-8,000 ft. Kodaikanal region, 283

Anstead, $R$. D., no. 104, 283

Anthony, A. W., no. 390,289 no. 412,289

Archer, William, Tasmania, 299

Arsène, Brother Gerfroy, Cerro de Santa Maria, Nov. 17, 1909, 289 no. 8863,289

Baker, Charles Henry, no. 547b, 288

Balansa, Benedict, no. 157, 277 no. 2268, 277

Balfour, Bayley, no. 659,300

Banks, Joseph, \& Daniel Charles Solander, New Zealand, 1768-1771, 295

Barkelew, F. E., no. 188, 289

Bartlett, $H$. $H$., no. 10737,279

no. 11291,280

no. 17432,275

Berlandier, Jean Luis, no. 929, 284 no. 2359,284

Blanchet, Jacques Samuel, no. 657, 274

Blodgett, $M r$., southern Florida, 304 Charlotte Harbor, 299

Blume, Carl Ludwig, in garden, Java, 283

Boldingh, $I .$, no. 2504, 275

Boorman, J.L., Gunnedah, Aug., 1907, 295

1 As might be expected in a large assortment of exsiccatae representing minor, subspecific categories, a few collections will be found to have been referred in one or several herbaria to one entity, in other herbaria to a slightly different one. In a few cases collectors have merged two collections, apparently of really different entities, under one number. In certain other cases the specimens may have come from different parts of the same shrub or tree, thus deceptively identifying one or several of them with the wrong entity. It may be noted, for instance, that poorly selected or somewhat fragmented specimens of Dodonaea viscosa var. vulgaris f. repanda may sometimes lack the large, repandly margined leaves of that forma and pass mistakenly for the f. Burmanniana. Or, an atypically small-leaved spray of $f$. Burmanniana will sometimes pass, in the absence of an ample suite of associate materials, as var. arborescens f. spatulata; and so on. Whatever the reason, however, in all such cases the collectors' numbers have been designated here and in the text proper as "p. p." or "pro parte." 
Brown, Stewardson, no. 608,291 no. 668,291

Brown, Stew., \& N. L. Britton, no. 138, 291

no. 823,291

no. 1022,291

no. 1043,292

no. 1061,292

no. 1068,292

Bryan, William Allanson, Diamond Head, Dec. 6, 1903, 301

Buchtien, Otto, no. 93, 291

no. 138, 291

no. 531,281

Burchell, William John, no. 4900, 286

Caly, Parramatta, 1803, 298

Tasmania, Dec., 1805, 303

Campbell, E., no. 5887, 293

no. 6052,275

Cárdenas, Martin, no. 2124, 291 no. 2845,291

Carleton, Mark Alfred, no. 619, 274

Chase, Virginius Heber, no. 7156, 284 no. 7401,273

Cheeseman, Thomas $F$., Woodhill, Oct., 1882,295

Chen, Luetta, no. 52A, 294

Christophersen, Erling, \& Edward $P$. Hume, no. 2364, 277

Chun, N.K., \& C. L. Tso, no. 43932, 294 no. 44503,282

no. 44637,282

Chung, H. H., no. 4677, 294

no. 4932,294

no. 5486,294

no. 7402,294

Claussen, $P$., no. 27, 291

Clemens, no. 5626, 277

Clemens, J., \& M. S. Clemens, no. 3210 pro parte (May 23-26), 300 no. 3210 pro parte (May-July), 282

Clemens, M. S., no. 475, 279

Coker, William Chambers, no. 444, 305 no. 567,305

Collins, Frank Shipley, no. 36, 292 no. 226,292

Conzatti, Cassiano, no. 1498, 299

Cook, Orator Fuller, \& G. B. Gilbert, no. 737, 290

Copeland, E. B., no. 351, 276

Cortes, P., \& M. D. Knapp, no. 23946, 276

Coulter, Thomas, no. 867, 289

Court, Miss O.M., sand-hills, Yeppoon, July, 1925, 295

Cranwell, Lucy May, Olof Hugo Selling, \& Carl Skottsberg, no. 2802, 301 no. 3259,301

Cuesta, Eugenio, no. 1079, 286

Curran, Hugh McCollum, no. 631, 274 no. 631,281
Curran, Hugo, no. 327, 276

Curtiss, Allen Hiram, no. 263, 278

no. 485 pro parte, 288,299

Degener, Otto, no. 11150,301

no. 11151,301

no. 11152,301

no. 11158,301

no. 11170,301

no. 11172,301

no. 14299,283

no. 14332,283

no. 15347,295

Degener, Otto, \& Emilio Ordoñez, no. 13537,283

no. 13703,283

no. 13710,283

no. 14205,308

Degener, O., D. LeRoy Topping, Martin Martinez, \& Felix C. Salucop, no. 11195,301

De l'Isle, G., no. 566, 282 no. 627,287

Diquet, Leon, barranca du Río Santiago, Dec., 1899, 289

Drège, Jean François, 1843, 286 no. $7532 a, 286$

Drouet, Francis, no. 2507, 274

Duckett, Francis, no. 236, 288

Dugès, Alfredo, Guanajuato and vicinity, Apr., 1898, 273

Dunlap, V. C., no. 480,274

Dupetit-Thonar, $M r$., Baie des Iles, 295

Duss, Père, no. 368, 276

no. 2904,306

no. 3627,275

East India Company, no. 1021/1, 294

Eastwood, Alice, bird forest near volcano, Aug. $1-16,1924,301$ no. 15952,296

Edwards, Mary Taylor, no. 736, 279

Eggers, Baron Heinrich Franz Alexander, along shore, Longbay, 275

July, 1881, 275

no. 2609,275

Ehrenberg, Carl (Karl) August, Santo Domingo, 306

Ekman, Erik L., no. 2603, 275

no. H.4942, 306

no. $H .9294,293$

Elmer, Adolph Daniel Edward, no. 10452,276

no. $10452 a, 276$

no. 12179,276

no. 16760,276

Emrick, George Monroe, no. 109, 279 no. 214,279

Erlanson, Eileen $W$. no. 5178, 300

Everist, S. L., no. 741, 298

no. 1825,298 
Eyerdam, W. J., \& A. A. Beetle, no. 22674,281

Eyerdam, W. J., A. A. Beetle, \& $E$. Grondona, no. 23634, 281

Faris, James A., no. 542, 275

Faurie, Abbé Urbain, no. 48, 287 no. 271,294

no. 278,301

Fendler, August, no. 2545, 281

Ferris, Roxana S., no. 8807, 286

Fisher, George L., no. 35441, 278

Fisher, Mary J., no. 17, 275

Fishlock, W. C., no. 47, 306

Fochtman, Sister Mary Noel, no. 217, 296

Forbes, Charles Noyes, Kilauea, 302

no. 305- $H$, 302

no. 308- $H, 302$

no. $966-H, 302$

no. 976- $H, 302$

no. $1032-H, 302$

no. 2009- $M, 301$

Forbes, C. N., with William T. Brigham $\&$ C. L. Thompson, Volcano Kilauea, Sept., 1908, 302

Forrest, George, no. 11233, 282

no. 11234, 276

no. 16868,282

Fosberg, Francis Raymond, no. 7498, 296

no. 10146, 302

no. 10148,302

no. 13184,301

no. 13185,301

Fosberg, F. R., \& Katherine Duker, no. 9049,301

Fosberg, Mrs. Violet Oliveira, no. 51, 302

Foxworthy, F. W., no. 629, 276

Franc, I., no. 637 (Dec., 1906), 295 no. 637 (July, 1909), 295 no. 2460,295

Francis, $W$. D., Wallumbilla, Sept. 15 and $16,1925,298,299$

Frank, Otto, Pinellas, Dec., 1899-Apr., 1900,273

Fraser, New South Wales, 1818, 287

Fredholm, Adolph, no. 5603, 288

Freney, F. T., Cooper's Plains, Nov., 1920,283

Frye, Theodore Christian, \& $E$. $M$. Frye, no. 3132, 278

Fuertes, Miguel, no. 189, 293 no. 317,275

Furness, Dwight R., Guanajuato, 279

Galathea Expedition, no. 3390, 302

Garber, Abram Paschal, St. Augustine, July, 1876, 299

Miami, Apr., 1877, 289

Gardner, George, no. 5978, 274

Geisse, Guillermo, Tulahuen, 1889, 281

Gentle, Percy H., no. 1775 (Gracie Rock), 289 no. 1775 (Sibun River), 278

Gentry, Howard Scott, no. 1389, 297

no. 1120,286

no. 4276, 279

Gillespie, $J$. W., no. 5388, 296 no. 8539,296

Gilman, $M$. F., no. 141, 296

Glaziou, Auguste François Marie, no. 52, 281

no. 14580,281

Goldman, Edward Alphonso, no. 230, 286

Graham, Herbert W., picnic grounds, Sabino Cabin, 296

Gressitt, J. Linsley, no. 1765, 294

Griffiths, David, no. 2132, 296 no. 2530,296

Guam Experiment Station, no. 328, 276

Gunn, Ronald, no. 377, 298

Hallier, $H$., no. 231, 276

Hancock, $M r$. $W$., no. 51, 301

Harris, J. Arthur, no. C14143, 296 no. $C 16572,296$

Harris, J. A., \& John V. Lawrence, no. C1598, 293

Harris, William, Santo Domingo, Sept. $9,1895,293$

no. 8578,293

no. 9658,293

no. 11753,293

Harris, T.J., no. 426, 292

Harshberger, John William, limestone sinks, Walsingham, 274, 292

Hart, John, no. 2025, 293

Hartman, C. V., no. 84, 286 no. 204,286

Hart, Constance, \& Marie C. Neal, no. 877, 302

no. 878,302

Hartweg, Theodor, no. 19, 284

Harvey, William Henry, Fiji Isls., Nov., 1855,283

Heinrichs, Erica, no. 22, 290

Heller, Amos Arthur, no. 4507, 275

Helms, Sabine, no. 940, 283

Henry, Augustine, Takow, 287

Herter, Guilelmus (given at times as W. G.), no. $701 b$ (5229), 291

no. $701 c, 291$

no. 5049,281

no. $96921,299,300$

Hess, W.E., \& F. L. Stevens, no. 4886A, 275

Hillebrand, William, Isl. Hawaii, 302

alt. 4,000 ft., Isl. Hawaii, July, 1865, 302

Hinton, George B., no. 295, 279

no. 4869,278

no. 10307,279

Hinton, G. B., et alii, no. 8974,278 no. 11712, 279 
Hioram, Brother, Palo Seco, Oct., 1912, 275

Hitchcock, Albert Spear, Crooked Isl., Nov., 1890, 305

Isl. Inagua, Dec. $3,1890,305$

no. 14638,302

no. 21411,298

no. 21582,290

no. 21720,290

Holdridge, L. R., no, 1009, 286

Holton, Isaac Farwell, Choachí, Jan. 18, 1854,274

Horne, J., no. 386, 295

Howell, John T., no. 8363 pro parte, 273, 289

Hubbard, C. E., no. 3478, 277

no. 4448,275

no. 5101,298

no. 5697,299

Hunnewell, F. W., no. 8755, 299

Jack, J. G., no. 8669, 292

Jaeger, no. 78, 293

Jahn, Alfredo, no. 807, 290

Jennings, Otto Emery, no. $276 B$, 292 no. 2267,292

Johnston, Ivan M., no. 3849, 284, 285 no. 4319,286

Johnston, J. R., no. 722, 275

Jones, Marcus Eugene, Mescal Mts., May 24, 1890, 296

alt. 3,000 ft., Sabino Canyon, Aug. 20, 1903, 296

Baboquivari Mts., Sept. 19, 1929, 296 trail down the Lagunas, Sept. 24, 1930,273

Kajewski, S. F., no. 120, 277

no. 296,308

no. 2458,277

Kanehira, Ryozo, no. 64, 290

$K a p p, L$. M., near Uniondale, July, 1921, 286

Kellerman, William Ashbrook, no. 7480, 280

no. 7627,278

Kelly, Mrs. G. Earle, no. 261, 302

Killip, Ellsworth Paine, no. 11269 pro parte, 280, 290

Killip, E. P., \& Albert Charles Smith, no. 19765 pro parte, 280,290

no. 21818,290

Kirk, T., North Isl., 295

South Isl., 303

no. 86,295

Knobloch, I., no. 5627, 286

$K o, S$. P., Po-ting to Seven Finger Mt., Apr. 23, 1932, 282

Koehler, H. J., no. 47, 289

Koepang, Boscharchitect, no. 16, 278

Kollmann, Dr., no. 1838, 276
Krukoff, B. A., no. 10707, 291

Kuntze, Otto, alt. 3,000 m., Río Tapacari, Mar. 19, 1892, 291

alt.2,000 m., Tunari Mts., Apr., 1892, 274

alt. 300 m., Cogmanskloof, Feb. 2, 1894,287

no. 1631,290

Langlassé, E., no. 102, 289

Lau, S. K., no. 74, 282

no. 1003,282

no. 2832,294

no. 3383,282

Lazar, Yusuf, no. 558, 294

Legrand, C. Diego, no. 792, 300

Lehmann, Friedrich Carl, no. 4800, 280

Lei, C. I., no. 396, 282

Lemmon, John Gill, Fort Lowell, 1880, 296

Lemmon, J. G., San Antonio Creek, 1880,296

Leon \& Edmond, no. 8567, 292

Leon \& Roca, no. 7982, 292

Leonard, Emery Clarence, no. 4203, 306 no. 4274,293

no. 8879,306

no. 8967,286

no. 8985,286

Leonard, E. C., \& Genevieve $M$. , no. 13812,275

no. 13945,306

no. 13946,306

no. 14995,293

no. 15351,275

Le Sueur, Harde, Río Bonito, Aug. 25, 1936, 286

Lewton, Frederick L., Disston City, Aug. 5, 1894, 273

Liang, H. Y., no. 62898,282

no. 65071,282

no. 65348,282

no. 66009,282

Liebmann, Frederik Michael, no. 2193, 278

Linden, Jean Jules, no. 2070, 286

Liou, T. N., no. 1596, 294

Lloyd, Francis Ernest, Vent Canyon, Apr. 24, 296

Pima Canyon, Nov. 11, 1906, 296

Loefgren, Albert, no. 10386, 291

Lorentz, Paul Guenther, \& Georg (Hans Emmo Wolfgang) Hieronymus, no. 1187,281

Luna, Antonio, no. 22, 292 no. 7668,292

Lyonnet, E., no. 17, 289

Macbride, J. Francis, no. 3335, 290

MacDaniels, L. H., no. 300, 278

Macowan, no. 717, 287 
Maiden, J. H., Mt. Warrah, Oct., 1897, 287

Risdon Cove, Feb., 1906, 299

Maiden, J. H., \& J. L. Boorman, Norfolk Isl., Nov., 1902, 277

Mail, no. 3647,276

Maingay, A.C., no. 459/2, 288

Maire, no. 6291 (ser. $B$ ), 282

Mandon, Gustave, no. 772, 291

March, Mr., no. 240, 293

no. 1335,275

Martius, Karl Friedrich Philipp (von), no. 397,274

Mason, Herbert L., no. 1551, 289

no. 1621,289

Maxon, William Ralph, no. 1197, 293

no. 1342,293

no. 1506,293

Maxon, W. R., \& E. P. Killip, no. 581, 293

no. 1342,293

McClure, $F$. A., herb. no. 7933,294

McFarlin, $J$. B., no. 8113, 289

$M c G r e g o r, G$. $M$., no. $M 73 / 37,282$

McGregor, Richard C., no. 460, 276 no. 43622,300

Mann, Horace, Jr., \& William $T$. Brigham, Kilauea, 302

no. 308,302

no. 410,302

no. 582,301

Matuda, E., no. 2015, 289

Mearns, Edgar A., no. 387 pro parte, 282, 300

Mélinon, Maroni, 1877, 274

Menzies, Archibald, alt. 6,000 ft., Hawaiian Isls., 301

Isl. Tahiti, 308

Merrill, Elmer Drew, no. 601, 276

no. 934,276

no. 2402,276

Mexia, Ynes, no. 7047, 280

Michael, Rev. N., no. 138, 277

Miller, O. B., no. 4081, 294

Millspaugh, Charles Frederick, no. 67, 292

no. 85,292

no. 1264,275

Millspaugh, C. F., \& Mrs. Clara Mitchell Millspaugh, no. 9311, 305 no. 9043,305

Mitchell, Elizabeth R., no. 5, 292

Moldenke, Harold N., no. 514, 289 no. 3576, 278

Moore, Albert Hanford, no. 2861, 292

Mueller, C. H., \& M. T. Mueller, no. 335,273

Munro, George C., no. 68, 301 no. 121,301

Nash, George Valentine, no. 149, 275 no. 1762,293
Nash, G. V., \& Norman Taylor, no. 955, 305

no. 1032,305

no. 1035,305

no. 1107,305

no. 1421,305

no. 3808,305

Naudin, Ch., Villa Thuret, Mar. 24, 1887, 298

Neal, Marie C., Kilauea Summer Camp, July 28, 1927 and Aug. 16, 1929, 302

Neal, M. C., Constance Hartt, \& John Martin, alt. $8,250 \mathrm{ft}$., summit of Mt. Hualalai, 302

Nelson, Aven, no. 10307, 296 no. 11276,296

Nelson, Aven, \& Ruth A. Nelson, no. 1151,296

Nelson, Edward William, no. 6087, 279 no. 6955,278

Nelson, E. W., \& Edward Alphonso Goldman, no. $7154,284,285$

no. 7438,273

Netherlands East Indies Forest Service, no. 16991,295

Nichols, George Elwood, no. 170, 293

Nicolás, Brother, Noria, Feb., 279 no. 5711, 279

Odashima, $K .$, no. 17825,294 no. 17880,294

Oersted, Anders Sandoë, no. 2994, 293

Oldham, Richard, no. 83, 294

Oliveira, J. M., \& Mrs. Violet Oliveira Fosberg, no. 97, 301

Orcutt, Charles Russell, no. 3297, 284 , 285

no. 3055,293

no. 5118,298

Ordoñez, Emilio, no. 12846, 301

Otero, J. I., no. 448, 275

Palmer, Edward, no. 127, 284

no. 143,286

no. 181,284

no. 247,286

no. 290,297

no. 495,299

Parks, Harold E., \& Susan Thew Parks, no. 22332,301

Parrish, W. F., Lowell, May 9, 1884, 296

Parry, Charles Christopher, \& Edwo. Palmer, no. 96, 284

Peck, Morton Eaton, no. 34, 289 no. 960,289

Peebles, $R$. H., no. 11653, 296

Penland, C. William, \& Robert $H$. Summers, no. 77, 290

Pennell, Francis Whittier, no. 1839, 280 no. 2352,300 
Perkins, J. R., no. 1238, 293

Pételot, A., no. 6259, 283

Petrie, $D$., no. 138, 295

Pittier, E. H., no. 211, 290

Pittier, Henri François, no. 24, 274

Playfair, no. 97, 287

Poole, C. E. Lane, no. 419, 283

Powell, T., no. 101, 308

Prain, Dr., Coonoor, Feb. 11, 1899, 283

Pringle, Cyrus Guernsey, by streams, Santa Catalina Mts., 296 no. 3461,279

Purpus, Carl Albert, no. 121, 299 no. 219,306

no. 3169,284

Ram, Bis, no. 436, 294

Ramos, Máximo L., no. 4912, 294 no. 27157,300

Reinecke, Dr., no. 356, 277

Remy, Jules, no. 568, 302

Riedel, Ludwig, \& B. Luschnath, no. 509, 291

Rimbach, $A$., no. 612 pro parte, 286, 290

Robinson, Charles Budd, no. 1, 276

no. 1056,300

no. 1094,283

Rock, Joseph Francis Charles, no. 3764, 302

no. 3766,302

no. 3767,302

no. 3852,302

Rogers, F. A., no. 30100,287

Rose, Joseph Nelson, no. 2406, 279

Rose, J. N., A. Pachano, \& George Rose, no. 23810,290

Rose, J. N., \& Joseph Hannum Painter, no. 6955,278

Rose, J. N., J. H. Painter, \& Joseph Sims Rose, no. 8797 pro parte, 278 , 279

Rose, J. N., Paul Carpenter Standley, \& P. G. Russell, no. 12804, 286

Rothrock, Joseph Trimble, no. 279, 305 no. 282,305

Rusby, Henry Hurd, no. 101, 291 no. 110,279

Santos, J. K., no. 31739, 294

Sargent, $F$. H., no. A28, 275

Saulière, $A .$, no. 40, 278

Sawada, $P$., no. 120,281

Schaffner, J.G. (often cited as Wilhelm), no. 306,284

no. 709,284

Schimper, Wilhelm Philipp, no. 705, 282

Schipp, William A., no. 494, 274

Schlagintweit, alt. 1,400-2,500 ft., $\mathrm{Mu}$ sakél, 300

Schlieben, H. J., no. 3609, 282

no. 4394, 276
Schlechter, (Friedrich Reichardt) Rudolph, no. 19118, 279

Schneider, Camillo, no. 2212, 276

Schott, Arthur, Bravo del Norte, 296

Schumann, Walther, no. 471, 284

Schweinfurth, Georg August, no. 743, 294

Seemann, Berthold, Sierra Madre, 289 no. 72, 295

Seler, Eduard, \& Caecilie Seler, no. 45, 279

no. 403,278

no. 649,278

no. 1525,279

no. 4253,278

no. 4435,278

Selling, Olof Hugo, cult., Kamehameha School garden, 301

Setchell, William Albert, \& H. E. Parks, no. 547,308

Setchell, W.A., \& Clara B. Setchell, Isl. Hawaii, June 23, 1924, 302

beyond Montague Pass, May 11, 1927, 287

Shafer, John Adolph, no. 2745, 306

no. 2775,306

no. 2981,292

no. 3590,292

no. 11985,292

no. 12433,292

Shear, Cornelius Lott, no. 4246, 296

Shreve, Forrest, dry slopes, Cinchona, May, 1903, 293

no. 5139,296

no. 6646,286

Sintenis, Paul (Ernst Emil), no. 108, 275

Skottsberg, Carl, no. 491, 302

no. 497,302

no. 522,302

no. 1121, s02

Skutch, Alexander F., no. 1005 pro parte, 274,280

Small, John Kunkel, no. 2314, 299

no. 4085,304

no. 9883,305

no. 10421,273

Small, J. K., \& Joel Jackson Carter, no. 1480,289

no. 2588,289

no. 3071,289

no. 3168,289

Small, J.K., J. J. Carter, \& G. K. Small, Big Pine Key, 289

no. 3283,289

Small, J. K., Alfred Cuthbert, \& Paul Matthaus, no. 9105,305

Small, J. K., \& J. B. DeWinkeler, no. 9037, 299

no. 9069,289

Small, J. K., \& George Valentine Nash, no. 90,289

Small, J.K., \& Small, no. 4783, 289 
Small, J.K., \& Percy Wilson, no. 2035, 298

Smith, Albert Charles, no. 86, 300 no. 826 pro parte, 283,295

no. 1284,277

no. 1425,295

Smith, Charles L., no. 92, 274 no. 824,280

Smith, E.J., Mt. Edwards, Sept., 1933, 295

Smith, Rev. Lucius C., no. 864, 279

Solis R., Fernando, no. 557, 274

Soukup, J., no. 782, 278

Spruce, Richard, no. 4978, 290

Standley, Paul Carpenter, no. 53038, 274 no. 62579,280

no. 62610,280

no. 65657,280

no. 82390,274

Stehlé, H., no. 207, 306

Steinbach, José, no. 6017, 300 no. 8602 pro parte, 281,291

Stevens, $F$. L., no. 2434, 275 no. 6152,306 no. 6289,306

Stevenson, J. A., \& J. R. Johnston, no. 1352,275

Stewart, Ralph R., no. 1076, 294 no. $16570 B, 300$

Steyermark, Julian, no. 31292, 278 no. 38305,280

Stokes, Mrs. A. M., no. 191, 307

Stolz, Ad., no. 82, 276

Stork, Harvey Elmer, no. 3158, 280

Stork, H. E., \& O. B. Horton, no. 10095, 290

no. 10413,281

no. 10784,281

Strachey, Richard, \& James Edward Winterbottom, alt. 1,500 ft., Simla Hills, 294

Swingle, Walter T., Allison Dam, July 10, 1931, 296

Tak, Tsang Wai, no. 202, 294

Ten, Peter Siméon, no. 184, 282

Terry, M. E., no. 1259, 280

Thode, J., no. A1101, 287

Thomson, T., alt. 1,000-2,000 ft., N. W. Himalaya, 294

no. 1450,294

Thurber, George, Rayon to Ures, 1852, 297

no. 909,297

Thwaites, no. 1158,283

Toumey, James William, Tueson, Jan.May, 1894, 296

Tucson, 1895, 296

Tracy, Samuel Mills, no. 7481 pro parte, 289, 299
Underwood, L. M., \& Robert Fiske Griggs, no. 179,275

United States Exploring Expedition, Fiji Isls., 295

Isl. Hawaii, 302

Samoa, 277

Tahiti, 277

Mauna Loa, at 8,000 ft. station, 302

United States South Pacific Exploring Expedition, Fiji Isls., 308

Isl. Tahiti, 1838-1842, 308

Usinger, R. L., no. 2, 302

Valeur, E. J., no. 851, 293 no. 910,293

Valerio, Manuel, no. 1364, 280

Vargas, C., no. 474,290

no. 475,291

no. 9781,300

Vaupel, $F$., no. 293,277

Védel, 1847, 295

Venturi, $S$., no. 2233,281

no. 8769,291

no. 9473,281

Vieillard, no. 246,300

Vogl, Padre Cornelio, no. 104, 290

Von Rozynski, $H$. W., no. 282,279 no. 398,279

no. 706,279

Von Tuerckheim, H., no. 2970, 293

Wang, C., no. 32893,282

no. 36485,282

Waterhouse, J. H. L., no. 327, 277

Weddell, no. 131 pro parte, 281, 291

White, C., alt. 3,500 ft., vicin. of Espia, 291

White, C. T., Crow's Nest, 299

Inglewood, Nov., 1922, 299

no. 1720,287

no. 1849,284

no. 5502, 302

no. 6349,284

no. 6906,277

no. 8326,299

no. 9503,299

White, Stephen S., no. 400, 286

no. 514,286

no. 1647,284

no. 2800,297

Wiegand, M. C., \& G. B. Upton, no. 4614,296

Wiggins, Ira L., no. 5913, 297

no. 6480,286

no. 7156,297

Wight, Robert, Mysore, 283

Wilder, Gerrit, Isl. Rarotonga, 1929, 301

Williams, Llewelyn, no. 7564, 300

no. 10107,281

no. 12305,274

no. 12369,274 
Williams, R. S., no. 190 pro parte, 278, 291

Williamson, H. B., Mt. Fero, Oct., 1927, 299

Wilson, E. H., Ootacamund, Oct. 14, 1921,283

no. 488,302

no. 10975,287

Wilson, Percy, no. 13, 274

no. 7405,305

no. 7500,305

no. 7602,305 no. 7700,305

no. 7875,306

Wood, D. D., no. 1747,276

Woronow, G., no. 2823,278

Wright, C., no. 2172,292

no. 2173,275

no. 3525,286

Wynd, F. Lyle, \& C. H. Mueller, no. 89, 300

Yeshoda, Mrs. Kanoth, no. 78, 294

no. $78 a, 294$ 





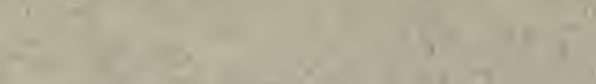

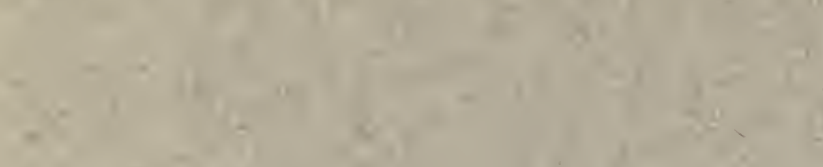

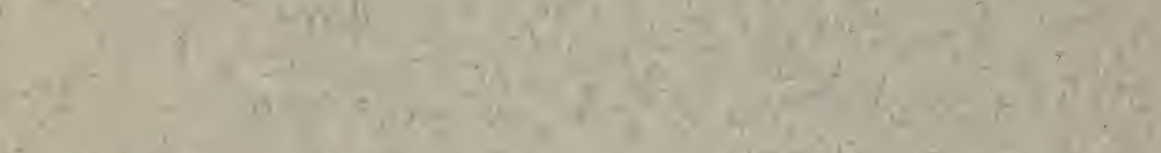

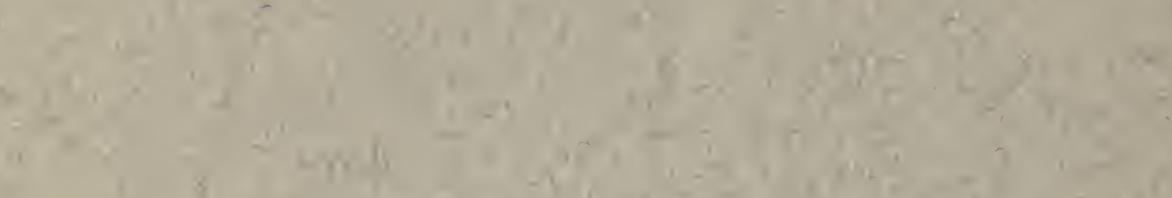

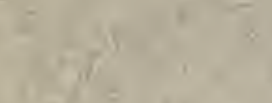

$1-\ln \left(\frac{1}{4}\right)^{2}=$

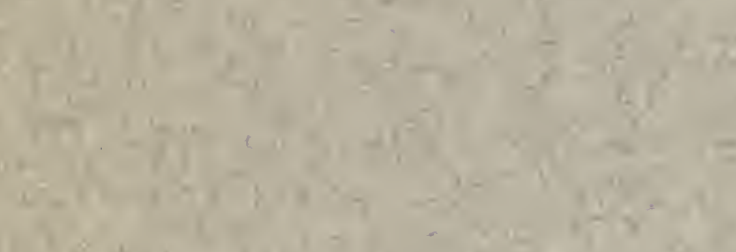

$\ln _{10}=-\infty$

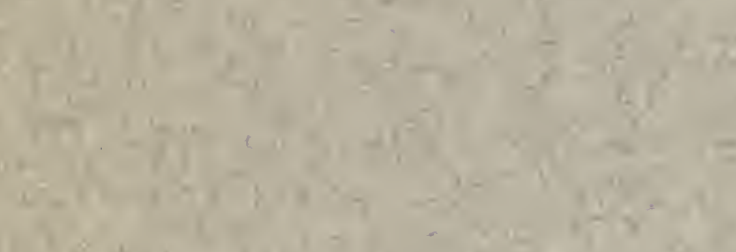

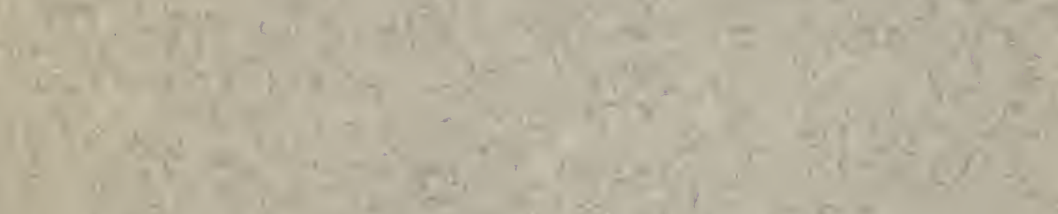

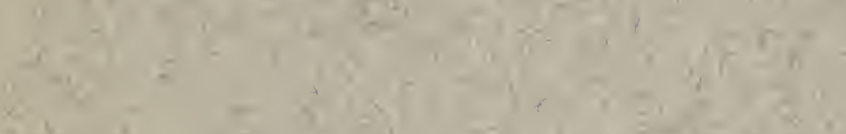

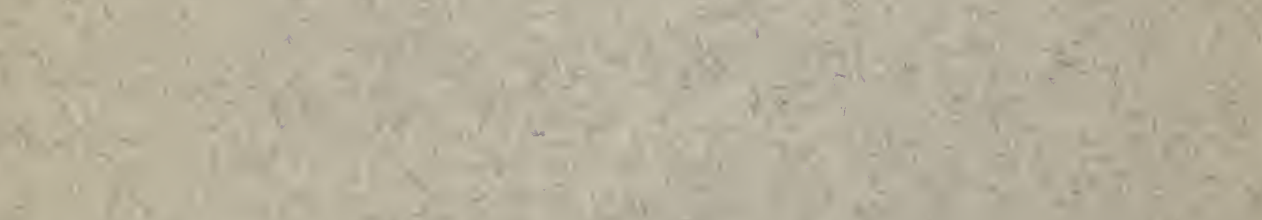
$-2 x^{2}+y^{2}$

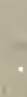

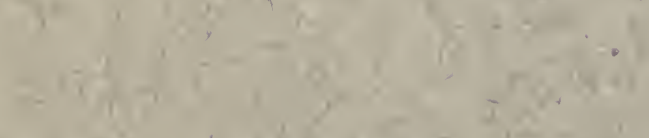

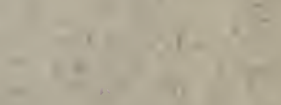
$y$ 


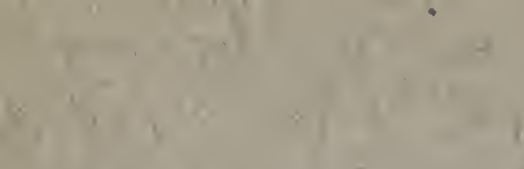

2.

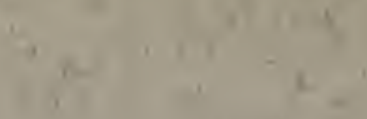

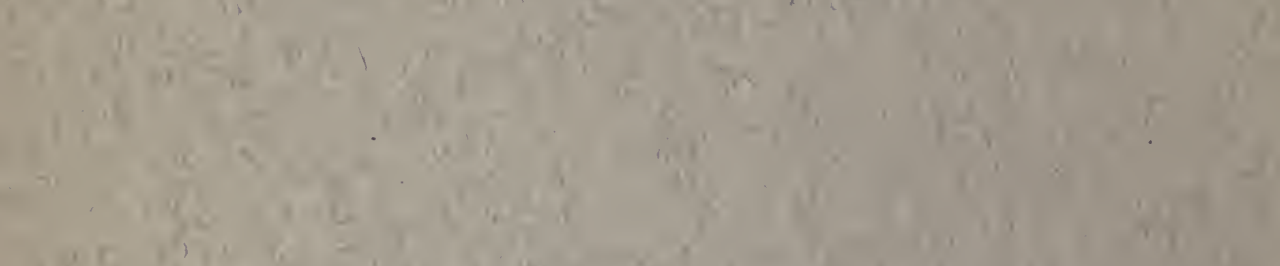

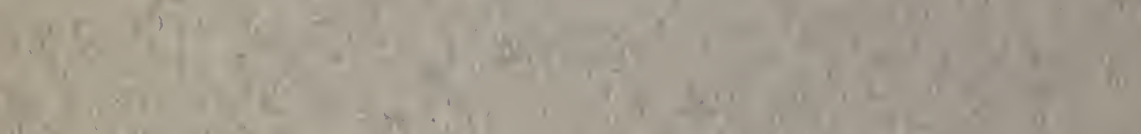
in:

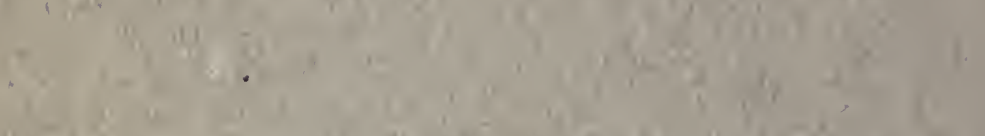

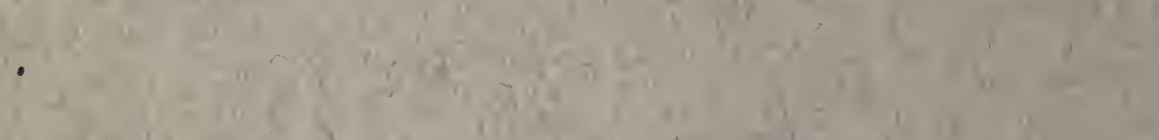

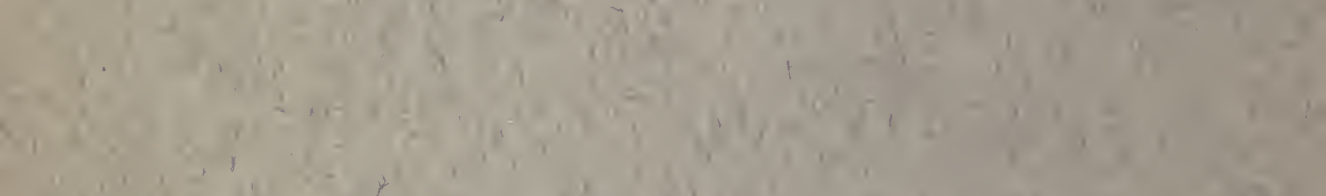

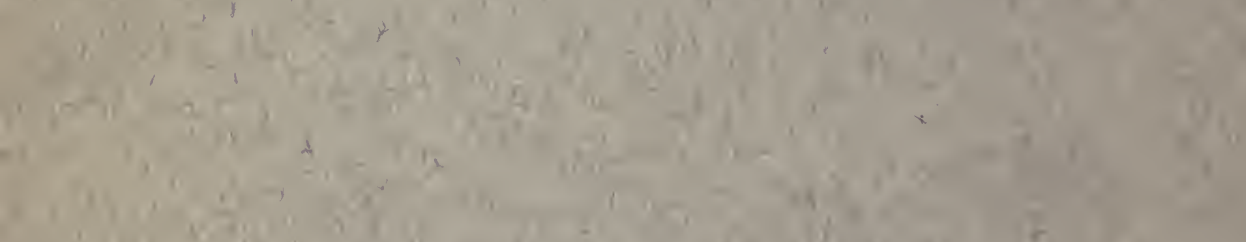

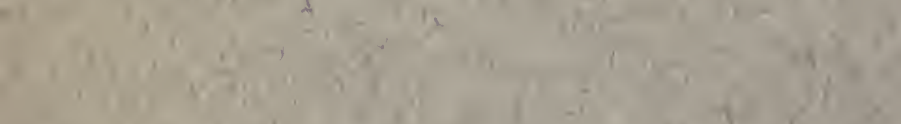

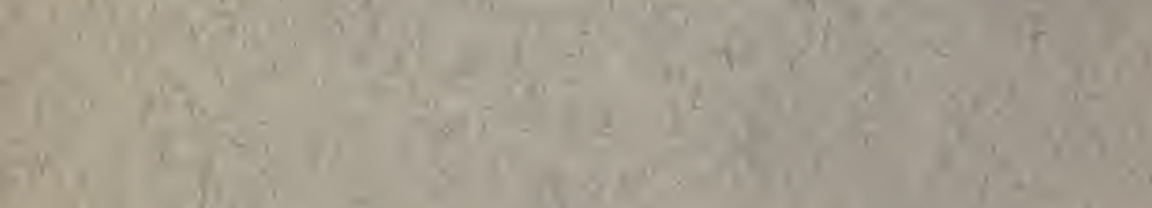

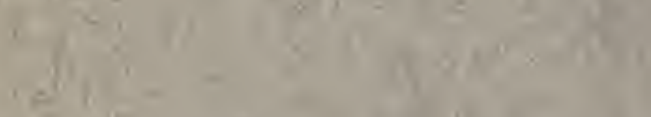

:

(1)

$$
\text { 1. }
$$

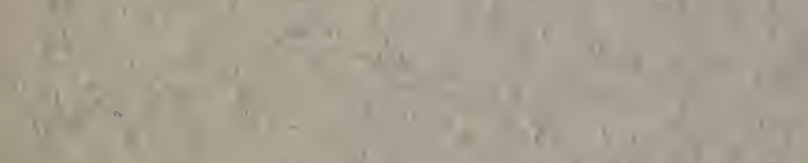

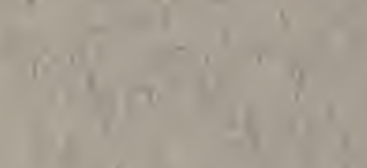

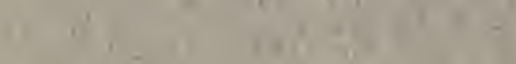

i $1 x^{-1}$

$=x^{-1}-x^{2} \quad x^{2}+x^{2}=\frac{1}{10}$ 